\title{
Tectonics
}

\author{
RESEARCH ARTICLE \\ 10.1029/2020TC006210 \\ Key Points: \\ - Weak décollements and ero- \\ sion control the occurrence of \\ in-sequence thrusting, duplexing, \\ and/or out-of-sequence thrusting \\ - Episodic migration of midcrustal \\ ramps explains the spatial \\ coincidence between the \\ interseismic and long-term uplift in \\ the Himalaya \\ - Critical taper wedge theory suggests \\ low apparent friction of the Main \\ Himalayan Thrust
}

Supporting Information:

- Supporting Information S1

Correspondence to:

L. Dal Zilio,

dalzilio@caltech.edu

Citation:

Dal Zilio, L., Ruh, J., \& Avouac, J.-P. (2020). Structural evolution of orogenic wedges: Interplay between erosion and weak décollements. Tectonics, 39, e2020TC006210. https:// doi.org/10.1029/2020TC006210

Received 23 MAR 2020 Accepted 6 OCT 2020

Accepted article online 14 OCT 2020

(C)2020. American Geophysical Union. All Rights Reserved.

\section{Structural Evolution of Orogenic Wedges: Interplay Between Erosion and Weak Décollements}

\author{
Luca Dal Zilio $^{1}(\mathbb{D})$, Jonas Ruh ${ }^{2}\left(\mathbb{D}\right.$, and Jean-Philippe Avouac ${ }^{1}(\mathbb{D})$ \\ ${ }^{1}$ Division of Geological and Planetary Sciences, California Institute of Technology (Caltech), Pasadena, CA, USA, \\ ${ }^{2}$ Structural Geology and Tectonics Group, Geological Institute, Department of Earth Sciences, ETH Zürich, Zürich, \\ Switzerland
}

\begin{abstract}
Orogenic wedges commonly display an inner wedge, where crystalline units have been exhumed, and an outer wedge formed by imbricated sedimentary units detached from the basement. Analog experiments have shown that similar structures can emerge naturally in the presence of weak décollements due to the interplay between erosion and deformation. In this study, we further investigate this hypothesis using two-dimensional, visco-elasto-plastic numerical models. Our experiments assume a basal and an intermediate décollement within the wedge. Experiments with a frictional strength of the basal décollement lower or equal to that of the intermediate décollement show a structural evolution of fold-and-thrust belts dominated by out-of-sequence thrusting. Conversely, when the intermediate décollement is weaker than the basal décollement, distinct outer and inner wedges are formed. This process leads to episodic migration of midcrustal ramps, tectonic underplating, and antiformal stacking facilitated by erosion. Comparison between our models and the Himalayan wedge suggests a low effective friction ( $\sim .10)$, which is probably due to dynamic weakening during large (M8+) Himalayan earthquakes. The deeper décollement, along which the lower plate thrusts beneath the High Himalaya, must be a thermally activated ductile shear zone with an apparent friction of $\sim 0.18$. Fold-and-thrust belts worldwide exhibit various architectures in which different décollement levels might be activated. Thus, our study provides a framework to help assess under which conditions a variety of structures observed in orogenic systems can arise.
\end{abstract}

\section{Introduction}

The internal part of mountain ranges generally consists of a structural culmination formed by basal accretion of crystalline thrust sheets, and an external part of imbricated thrusts formed by frontal accretion of sedimentary units (Figure 1) (Pfiffner, 2017, for a review). Basal accretion typically occurs through the formation of duplexes (Boyer \& Elliott, 1982): Ramps connecting different décollement levels migrate into the lower plate; the horses formed between the successive ramps are then transferred to the upper plate through a process often called tectonic underplating. Studies based on analog (e.g., Gutscher et al., 1998; Konstantinovskaia \& Malavieille, 2005; Kukowski et al., 2002) and numerical modeling (e.g., Borderie et al., 2018; Ruh et al., 2012; Simpson, 2009; Stockmal et al., 2007) have shown that such a structural evolution can emerge due the presence of a weak décollement within the brittle upper crust and is favored by erosion (e.g., Selzer et al., 2008). The interplay between deformation and erosion exerts an important influence on the evolution of orogens (e.g., Avouac \& Burov, 1996; Willett, 1999).

This view of the structural evolution of orogens applies in particular to the Himalaya (e.g, DeCelles et al., 2001; Hauck et al., 1998; Hubbard et al., 2016; Ghosh et al., 2020; Robinson, 2008; Schelling \& Arita, 1991; Shen et al., 2020; Srivastava \& Mitra, 1994; Webb, 2013; Yin, 2006) (Figures 2a and 2b): The external part of the range is a fold-and-thrust belt, the Sub-Himalaya, formed above a relatively shallow décollement at a depth of $\sim 5-7 \mathrm{~km}$ (e.g., Avouac, 2015) (Figure 2b). This décollement extends beneath the Lesser Himalaya, where a duplex structure associated with midcrustal ramps roots into a deeper décollement beneath the High Himalaya and Southern Tibet (Figure 2b). The duplex and associated underplating process account for the structure, the inverted metamorphic gradient, and the exhumation history revealed by thermochronological ages and the zone of higher uplift at front of the High Himalaya (Bollinger, Avouac, Beyssac, et al., 2004; Célérier et al., 2009; Coutand et al., 2014; Herman et al., 2010). Out-of-sequence thrusting at front of the High Himalaya has been invoked in the Miocene (Hubbard et al., 2016) and possibly 


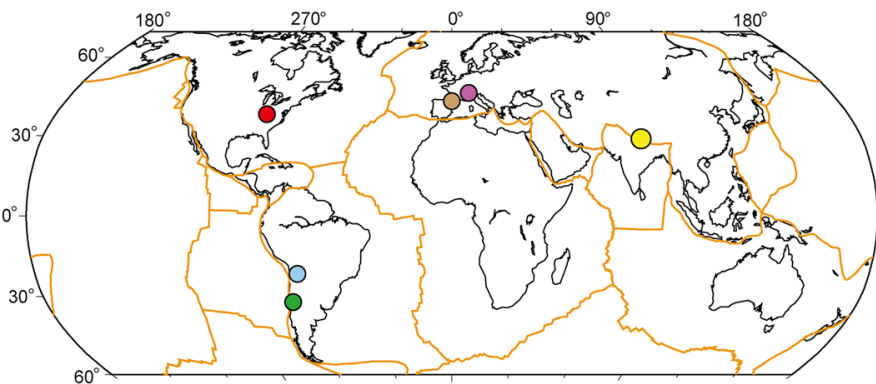

Southern Appalachians

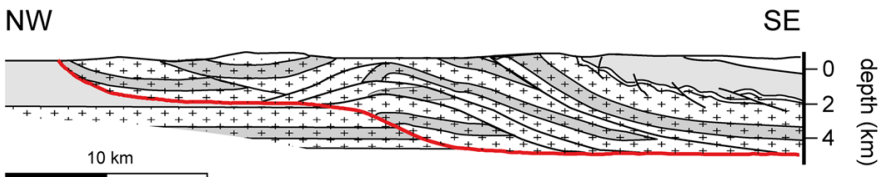

Subandean, NW Argentina

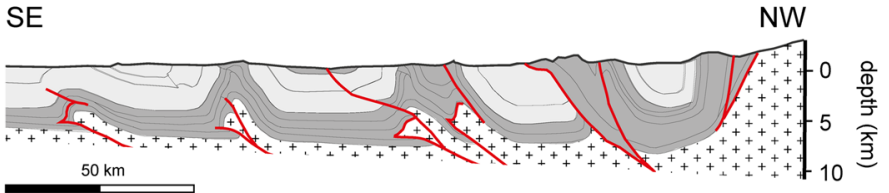

Malargüe fold-and-thrust belt, Cordillera of Argentina

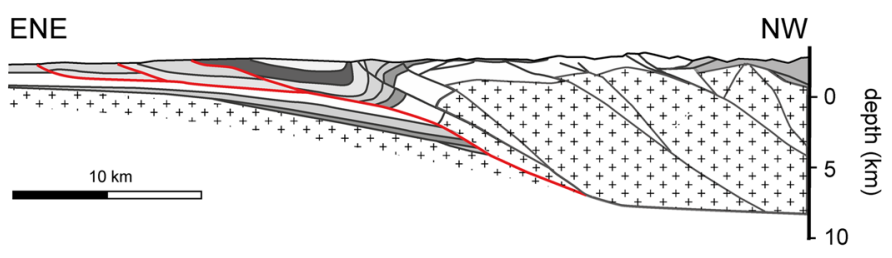

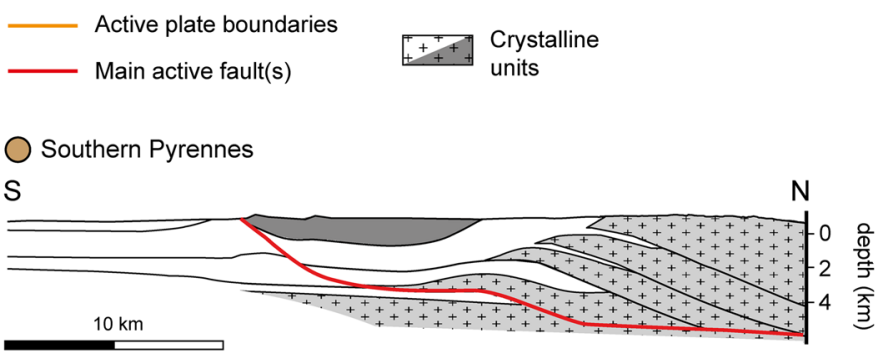

Nepal - Himalaya

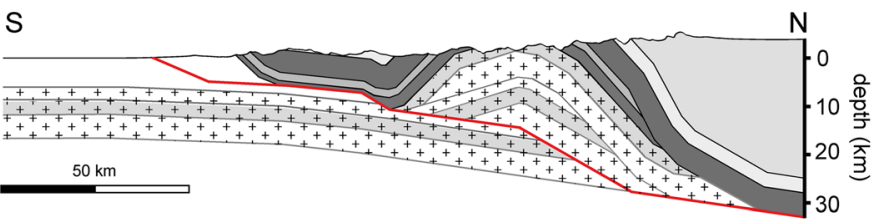

Jura Mountains, Alpine foreland

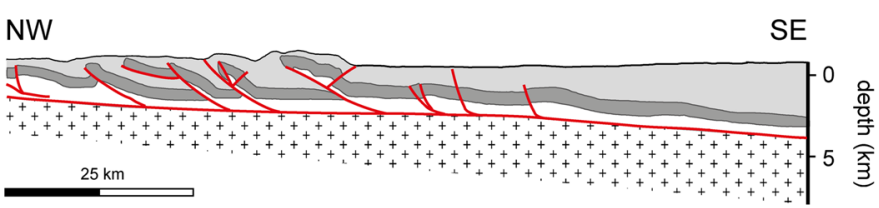

Central Alps

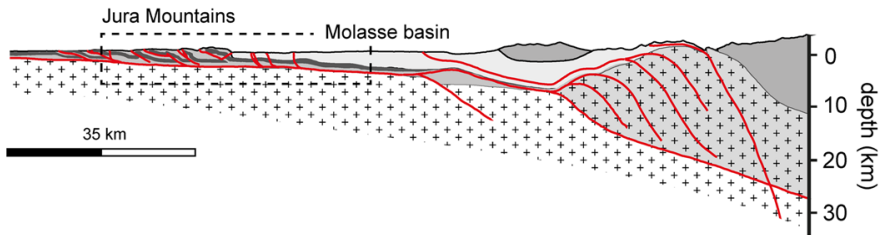

Figure 1. Examples of fold-and-thrust belts worldwide. Southern Appalachians = modified after Kulander and Dean (1986); Sub-Andean, NW Argentina = modified after Echavarria et al. (2003); Malargüe fold-and-thrust belt (Cordillera of Argentina) = modified after Pfiffner (2017); Southern Pyrennes = modified after Martínez and Vergés (1988); Nepal Himalaya = modified after Hubbard et al. (2016); Jura Mountains (Alpine foreland) = modified after Sommaruga (1999); Central Alps = modified after Burkhard and Sommaruga (1998). Red lines indicate the main fault(s).

at present (Wobus et al., 2005); however, this mechanism can only play a limited role due to the observation that the entire convergence $\left(\sim 18-20 \mathrm{~mm} \mathrm{yr}^{-1}\right)$ across the mountain range is transferred to the frontal structures of the Sub-Himalaya (Burgess et al., 2012; Lavé \& Avouac, 2000; Stevens \& Avouac, 2015).

Not all orogens have however developed duplex structures as clear as in the Himalaya; it is common to observe out-of-sequence thrusting within the outer or inner parts of orogenic wedges. In this study, we investigate the factors that determine tectonic underplating, duplexing, and antiformal stacking, and/or out-of-sequence thrusting. We present two-dimensional (2-D) numerical experiments with a simple setup inspired by the analog experiments of Konstantinovskaia and Malavieille (2005), which produced underplating and a duplex structure resulting in a structural evolution strikingly similar to that of the Himalayan orogen (Figure 3). The key factors in their experiments are the presence of two weak horizontal layers and erosion at the surface. It is therefore interesting to explore how the structural evolution observed in such an experiment varies when the model parameters are varied. Our numerical experiments can indeed reproduce the evolution observed in analog experiments and can be used to quantify the conditions needed to obtain a structural evolution similar to that observed in the Himalaya. They additionally allow to explore in more detail how the mechanical properties of basal décollements and nonlinear erosion may favor the episodic migration of midcrustal ramp(s) and the formation of a duplex structure. 
(a)

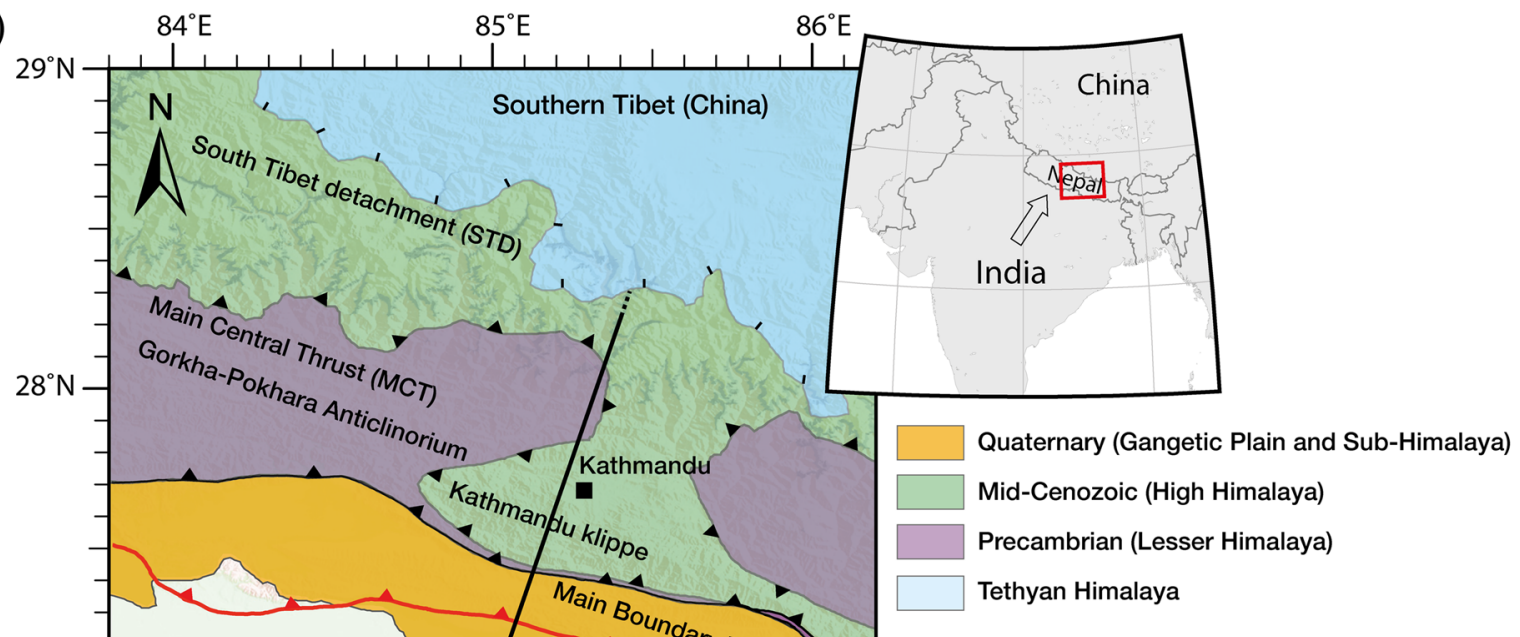

(b)

(b)

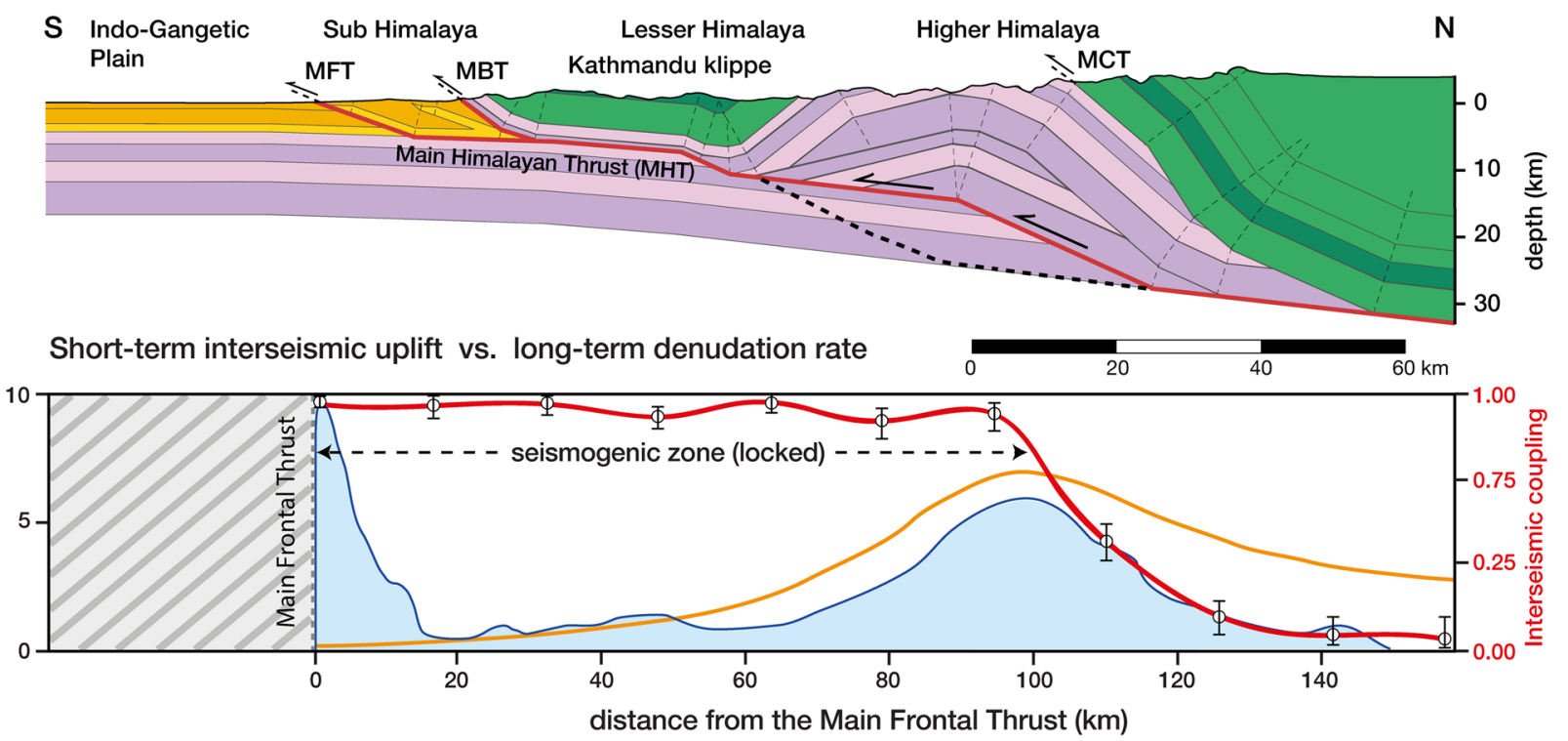

Figure 2. Geological map, cross-section, long-term denudation rate, and short-term interseismic vertical velocities across the central Himalaya of Nepal. (a) Geological map of the Nepal Himalaya showing major faults. Modified after Avouac (2015). The solid black line indicates the location of the structural profile. (b) Cross section of the Himalayan wedge showing the duplex structure and the geometry of main faults at depth (MFT = Main Frontal Thrust; MBT = Main Boundary Thrust; MCT = Main Central Thrust; MHT = Main Himalayan Thrust). Red line indicates the main fault. Modified after Hubbard et al. (2016). (c) Comparison between interseismic coupling (solid red line and error bars; from Ader et al., 2012), leveling measurements of interseismic uplift (solid orange line; from Jackson \& Bilham, 1994); and long-term denudation rate (solid blue line; from Lavé \& Avouac, 2001).

\section{Structural Evolution of the Himalaya}

The Himalayan arc formed as a result of the collision between India and Asia since 75 Ma (e.g., Yin \& Harrison, 2000). Due to frontal accretion, crustal shortening resulted in a sequence of major thrust faults: From north to south, these are the Main Central Thrust (MCT), the Main Boundary Thrust (MBT), and the Main Frontal Thrust (MFT) faults (e.g., Gansser, 1964; Le Fort, 1975; Meigs et al., 1995) (Figures 2a and $2 \mathrm{~b}$ ). These faults were likely activated in a southward propagating sequence, and they all merge at depth with the Main Himalayan Thrust (MHT), which dips gently to the north beneath the Lesser Himalaya (Avouac, 2015). This décollement, or bed-parallel fault, in turn steepens downward into a midcrustal ramp that dives beneath the High Himalaya before flattening again northward under the Tethys Himalaya of southern Tibet (Figure 2b). The presence of such a midcrustal ramp has been proposed and discussed by 

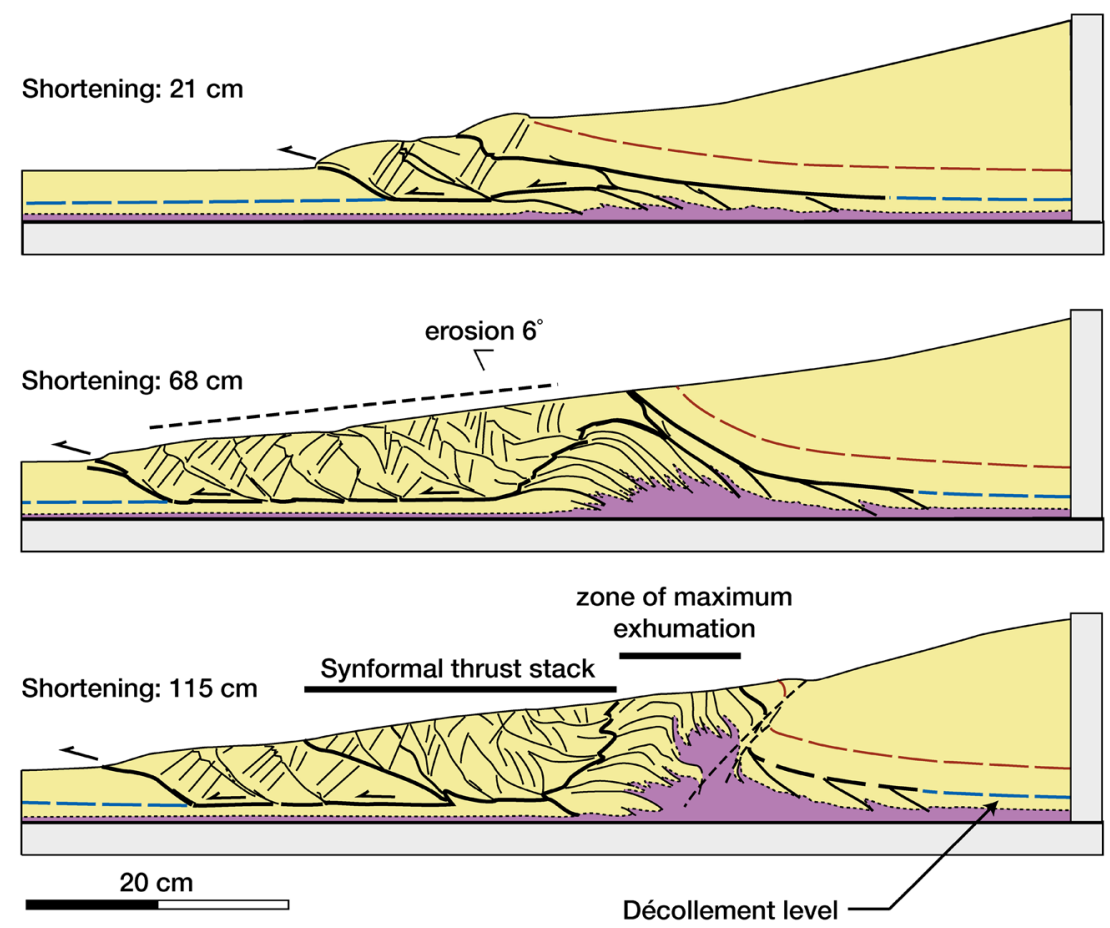

Figure 3. Three deformation stages for model thrust wedge with a d 'ecollement level (modified after Konstantinovskaia \& Malavieille, 2005). The décollement level acts from the beginning of shortening to control the thickening of the wedge. The purple material located at depth below the décollement level is underplated under the frontal part of the wedge. The exhumation of the basal layers from below the detachment level induces the formation of a dome-shaped structure. A $6^{\circ}$ slope angle has been chosen for the imposed erosion profile to represent an overcritical taper with low basal friction setting.

several investigators, on the basis of analyses of microseismicity (Pandey et al., 1995), seismic reflection (e.g., Hauck et al., 1998), magnetotelluric sounding (Lemonnier et al., 1999), geodetic data (e.g., Bilham et al., 1997), uplift rate (e.g., Lavé \& Avouac, 2001) and balanced structural section (e.g., Hubbard et al., 2016; Schelling \& Arita, 1991), and it seems a necessary component to produce the large Gorkha-Pokhara Anticlinorium (Brunel, 1986; Pêcher, 1989), which extends through most of central Nepal and the High Himalaya (Figures 2a and 2b). During the short-term (interseismic) period, the MHT appears to be locked from the surface to a distance of $\sim 100 \mathrm{~km}$ down dip (Figure 2c), corresponding to a depth of 15 to $20 \mathrm{~km}$. The transition zone between the locked segment and the portion which is creeping at the long-term slip rate seems to coincide with the belt of midcrustal microseismicity underneath the Himalaya (Ader et al., 2012; Pandey et al., 1995). The uplift velocity, derived from interferometric synthetic aperture radar (InSAR) (Grandin et al., 2012) and leveling measurements (Jackson \& Bilham, 1994), are $\sim 6-7 \mathrm{~mm} \mathrm{yr}^{-1}$ at the front of the High Himalaya, whereas the horizontal slip rate along the deep shallow-dipping portion of the MHT is $\sim 18-21 \mathrm{~mm} \mathrm{yr}^{-1}$ (Ader et al., 2012). These rates are comparable to geological and geomorphic estimates, indicating an essentially elastic geodetic surface strain (Dal Zilio, Jolivet, et al., 2020; Stevens \& Avouac, 2015). Previous studies noticed that the interseismic uplift peak seems to match spatially with the long-term erosion (Burbank et al., 2003) and the uplift peak deduced from the study of trans-Himalayan river incision (Lavé \& Avouac, 2001), which suggests denudation rates of 4-6 mm yr ${ }^{-1}$ (Figure 2c). Different tectonic mechanisms have been proposed to explain the marked increase in uplift rates from the Lesser Himalaya to the High Himalaya, such as (1) thrusting over a midcrustal ramp, (2) duplexing, or (3) out-of-sequence thrusting. However, neither ramp overthrusting nor out-of-sequence thrusting can explain the growth of the Himalaya over the long-term term as these mechanisms do not involve any accretion (Bollinger, Avouac, Beyssac, et al., 2004). Hence, a possible way to explain the transfer of material from the Indian crust to the Himalayan wedge is tectonic underplating (Bollinger, Avouac, Beyssac, et al., 2004; Robinson, 2008). In particular, tectonic underplating-through the development of a duplex system at midcrustal depth-has been proposed as the dominant mechanism of crustal accretion over the last $~ 10-15 \mathrm{Myr}$ (Herman et al., 2010). According to this process, the flat-ramp-flat shape of the plate interface is expected to 
cause permanent uplift above the ramp, whose surface expression is subdued by erosion. Over longer time scales, episodic brittle failure within the Indian plate may bypass the MHT and lead to a southward migration of the midcrustal ramp (black dashed line; Figure 2b). Episodic forward migration of midcrustal ramps, combined with a delayed erosional response to such episodes, may be responsible for the observed coincidence between the peak of geodetic (interseismic) uplift and the peak of net uplift inferred from riverbed morphology, which cannot be explained by a steady-state model of mountain building (Grandin et al., 2012).

\section{Methods}

\subsection{Governing Equations and Rheological Model}

The employed numerical code combines conservative finite differences on a fully staggered grid and marker-in-cell techniques (T. V. Gerya \& Yuen, 2003; Ruh, 2017). The momentum and conservation of mass for an incompressible material are implicitly solved using a visco-elasto-plastic rheology (e.g., T. Gerya \& Yuen, 2007) on the nondeforming Eulerian grid. The advection of physical properties including viscosity and plastic strain is performed with the displacement of Lagrangian markers. The implemented visco-elastic relation between deviatoric stresses $\sigma_{i j}$ and strain rate $\dot{\varepsilon}_{i j}$ follows a non-temperature-dependent Maxwell-type form:

$$
\dot{\varepsilon}_{i j}=\frac{1}{2 \eta} \sigma_{i j}+\frac{1}{2 G} \frac{D \sigma_{i j}}{D t}
$$

where $G$ is shear modulus and $\eta$ is effective viscosity. $D \sigma_{i j} / D t$ is the objective corotational time derivative of visco-elastic stresses solved using a time explicit scheme and discretized by applying first-order finite difference:

$$
\frac{D \sigma_{i j}}{D t}=\frac{\sigma_{i j}^{t}-\sigma_{i j}^{t-1}}{\Delta t},
$$

where

$$
\sigma_{i j}^{t}=2 \eta \dot{\varepsilon}_{i j} Z+\sigma^{t-1}(1-Z)
$$

and $Z$ is the visco-elasticity factor

$$
Z=\frac{\Delta t \cdot G}{\eta+(\Delta t \cdot G)}
$$

Plastic behavior is taken into account assuming a nonassociative Drucker-Prager yield criterion (Prager \& Drucker, 1952). Evaluated at each Lagrangian marker, plasticity sets in when the second invariant of the deviatoric stress tensor reaches the local pressure-dependent yield strength $\left(\sigma_{I I}^{\prime}=\sigma_{\text {yield }}\right)$

$$
\begin{gathered}
\sigma_{I I}=\sqrt{\frac{1}{2} \sigma_{i j}^{2}} \\
\sigma_{\text {yield }}=P \cdot(1-\lambda) \cdot \sin (\phi)+C \cdot \cos (\phi),
\end{gathered}
$$

where $C$ is the cohesion, $\phi$ the friction angle, and $P$ the pressure. The effective friction $\left(\mu_{e f f}\right)$ is calculated as

$$
\begin{gathered}
\mu_{\text {eff }}=\tan (\phi)(1-\lambda) \\
\lambda=\frac{P_{\text {fluid }}}{P},
\end{gathered}
$$

where $\tan (\phi)$ is the static friction and $\lambda$ is the pore fluid pressure factor, given by the ratio between the fluid $\left(P_{\text {fluid }}\right)$ and dynamic pressure $(P)$.

\subsection{Model Setup: Boundary Conditions and Initial Geometry}

The 2-D model setup consists of a $250 \times 50 \mathrm{~km}$ computational domain (Figure 4). The Eulerian grid resolution consists of $1,001 \times 201$ nodes resulting in nodal cells measuring $250 \times 250 \mathrm{~m}$. Each nodal cell 


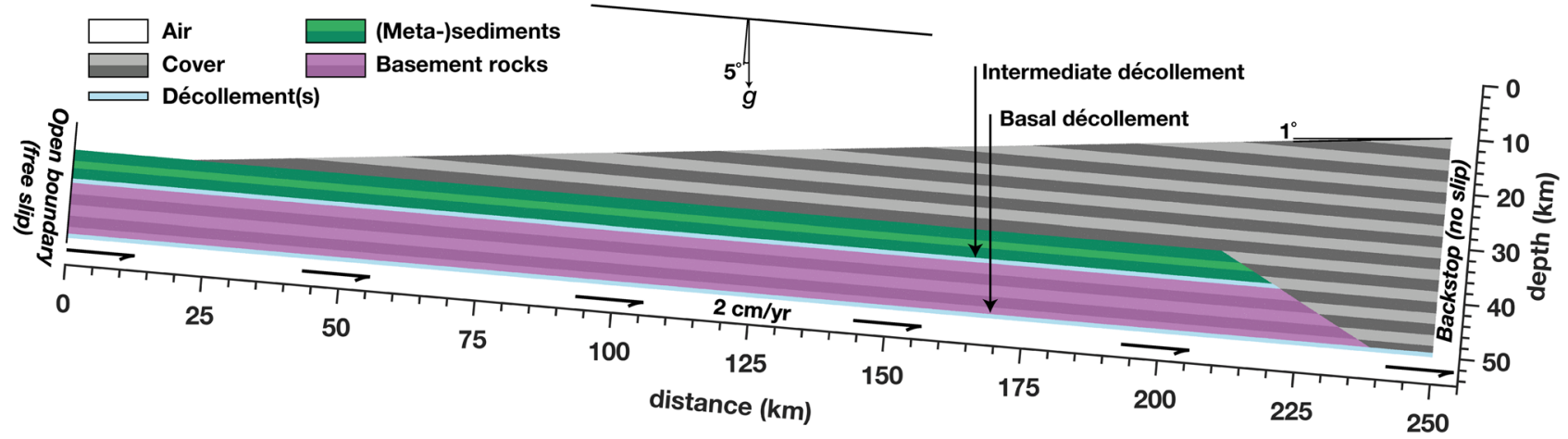

Figure 4. Model setup. The wedge is assumed homogeneous, except for the two weaker layers of décollement. A layering is introduced (represented by the sedimentary cover, metasediments, and basement units) to help visualize the structural evolution of the wedge during deformation. Arrows show velocity boundary conditions. The gravitational force is rotated $5^{\circ}$ anticlockwise to mimic an inclination of the wedge base toward the backstop (right). The effective topographic slope is $1^{\circ}$.

initially contains 16 Lagrangian markers carrying material properties with respect to their rock phase. A free-surface boundary condition along the crust/air interface is implemented by introducing a "sticky air" layer (Schmeling et al., 2008) with low density $\left(1 \mathrm{~kg} / \mathrm{m}^{3}\right)$ and viscosity $\left(10^{17} \mathrm{~Pa} \mathrm{~s}\right)$. The gravitational acceleration of $9.81 \mathrm{~m} \mathrm{~s}^{-2}$ is tilted by $5^{\circ}$ to the vertical axis of the model box, mimicking the low-angle inclination of the Main Himalayan Thrust (e.g., Elliott et al., 2016; Figure 4). The applied lateral velocity boundary conditions resemble those of an analog sandbox model. The top boundary has a free-slip boundary condition, whereas the lower boundary has an imposed boundary-parallel velocity of $20 \mathrm{~mm} \mathrm{yr}^{-1}$. The right side is a rigid no-slip boundary, acting as a backstop. On the left side of the model, markers enter the Eulerian box with a velocity of $20 \mathrm{~mm} \mathrm{yr}^{-1}$ and free-slip is applied vertically.

The initial geometry consists of a sedimentary sequence, a basement layer, and a protowedge (Figure 4). The air level is at $34 \mathrm{~km}$ height at the left boundary, decreasing toward the right with an angle of $6^{\circ}$. The initial sedimentary sequence is of $5 \mathrm{~km}$, whereas the basement thickness is of $10 \mathrm{~km}$. These two lithologies are separated by a basal and an intermediate décollement, each $750 \mathrm{~m}$ thick (i.e., three Eulerian cells). The depth of the intermediate décollement has been chosen for all simulations to be at $5 \mathrm{~km}$ depth. This choice is consistent with structural analyses across the Himalaya, which suggest a shallow thrust fault flattening at depth of $\sim 5 \mathrm{~km}$ (e.g., Avouac, 2015). This is also consistent with the fact that weak layers in frictional fold-and-thrust belts are commonly made of high-pressured or overpressured rocks, which needs a certain depth of burial so that the water pressure is sufficient to reach the failure criterion (e.g., Platt, 1990). The visco-elasto-plastic parameters of the lithologies used are based on a range of laboratory and numerical experiments (Table 1).

Table 1

Rheological Parameters

\begin{tabular}{llcccccc}
\hline Material & \multicolumn{1}{c}{ Rheology } & $\rho_{0}^{\mathrm{a}}$ & $C^{\mathrm{b}}$ & $\mu_{s}^{\mathrm{c}}$ & $G^{\mathrm{d}}$ & $\lambda$ & Flow law \\
\hline Air & linear & 1 & 0 & 0 & 100 & 0 & $A=1 \cdot 10^{-17}, n=1, \mathrm{E}_{a}=-, V_{a}=-, k=200$ \\
Proto-wedge & Quartz-Diorite $\mathrm{e}, \mathrm{f}^{\mathrm{f}}$ & 2,700 & 10 & 0.5 & 25 & 0.4 & $A=1.5 \cdot 10^{-17}, n=3.2, E_{a}=2.38 \cdot 10^{5}, V_{a}=0.80, k=2.5$ \\
(Meta)sediments & Wet quartzite $^{\mathrm{f}}$ & 2,700 & 10 & 0.5 & 25 & 0.4 & $A=3.99 \cdot 10^{-18}, n=2.4, E_{a}=1.54 \cdot 10^{5}, V_{a}=1.20, k=2.5$ \\
Décollements & Wet quartzite $^{\mathrm{f}}$ & 2,700 & 10 & 0.5 & 25 & $0.5-0.85$ & $A=3.99 \cdot 10^{-18}, n=2.4, E_{a}=1.54 \cdot 10^{5}, V_{a}=0.80, k=2.5$ \\
Basement & Quartziteg & 2,800 & 10 & 0.5 & 25 & 0.4 & $A=1.26 \cdot 10^{-16}, n=4.0, E_{a}=2.23 \cdot 10^{5}, V_{a}=0.80, k=2.5$ \\
\hline
\end{tabular}

Note. The $\rho_{0}$ is the reference density $\left(\mathrm{kg} / \mathrm{m}^{3}\right), C$ is cohesion (MPa), $\mu_{s}$ is the static friction coefficient, $G$ is the shear modulus (GPa), $\lambda$ is the pore fluid pressure factor, $A$ is the preexponential factor $\left(\mathrm{Pa}^{-n} \mathrm{~s}^{-1}\right), n$ is the stress exponent, $E_{a}$ is the activation energy $(\mathrm{J}), V_{a}$ is the activation volume $(\mathrm{J} / \mathrm{bar})$, and $k$ is thermal conductivity $(\mathrm{W} / \mathrm{m} / \mathrm{K})$.

${ }^{a}$ From Bollinger et al. (2006). ${ }^{b}$ From Cattin and Avouac (2000). ${ }^{c}$ From Di Toro et al. (2011). $\quad{ }^{d}$ From Gillespie et al. (1992). $\quad{ }^{e}$ From Carter et al. (1982).

${ }^{f}$ From Ranalli (1995). ${ }^{g}$ From Gleason and Tullis (1995). 


\subsection{Surface Diffusion}

We looked for a relatively simple two-dimensional law that could mimic erosion and sedimentation at the scale of an orogenic wedge. The evolution of a landscape results from the combination of weathering, transport, and deposition. Although many factors, such as the lithologies and climate, may control this evolution, quite simple mathematical models describing the geometrical evolution of the morphology at the small scale have been proposed and tested successfully (e.g., Andrews \& Bucknam, 1987; Avouac \& Burov, 1996; Dal Zilio et al., 2018; Simpson, 2006). We thus implemented a nonlinear diffusion equation to calculate erosion rates for plane strain models in which the surface is represented on a line:

$$
\frac{\partial h}{\partial t}=k^{*}\left(x, h, \frac{\partial h}{\partial x}\right) \frac{\partial^{2} h}{\partial x^{2}}
$$

where

$$
k^{*}\left(x, h, \frac{\partial h}{\partial x}\right)=k(x)\left(\frac{\partial h}{\partial x}\right)^{m}
$$

$k$ is the mass diffusivity coefficient expressed in unit of area per time $\left(m^{2} y r^{-1}\right), x$ is the horizontal distance, $h$ is the topography elevation, and $m$ is the diffusion coefficient. We considered values for $m$ of 2 and for $k$ varying between $10^{3}$ and $10^{4} \mathrm{~m}^{2} \mathrm{yr}^{-1}$, which yield denudation rates of the order of a few tenths to $1 \mathrm{~mm} \mathrm{yr}^{-1}$.

\section{Results}

In this section, we outline the main results obtained from three numerical experiments in which we progressively increase the complexity of the model setup. The first numerical experiment (Model-M1) includes only a single (basal) décollement. The second numerical experiment (Model-M2) accounts for two frictional weak layers, namely, a basal and an intermediate décollement. These two models do not include the effect of erosion. The third model (Model-M3), which includes two décollements and nonlinear erosion/sedimentation, is our reference model. Lastly, we perform 42 models in which we test different effective friction on the basal and the intermediate décollements. We discuss the impact of both décollements on the structural evolution of fold-and-thrust belts. In particular, we analyze whether the models are characterized by a break-forward thrust sequence (i.e., in-sequence thrusting) and/or by thrusts that do not obey the in-sequence deformation style (i.e., out-of-sequence thrusts). This latter includes both front-to-back propagation and/or thrust cutting through already deformed thrust sheets (Morley, 1988).

\subsection{Single Décollement (Model-M1)}

When assuming a sufficiently weak basal layer $\left(\mu_{\text {eff }}<0.25\right)$, typical simulations show that deformation starts from the backstop and migrates forward by frontal accretion, forming in-sequence, forward verging thrust sheets (Figure 5). This process results in a single wedge formed by thrusting along faults, which all root into the basal décollement.

Stresses in the basal décollement exceed yield stresses at a distance of $\sim 100 \mathrm{~km}$ from the backstop than the actual deformation front in the overburden sequence (Figure $5 b$ ). The frontal thrust is active until the stress along the décollement in front of the wedge toe exceeds its yielding strength. Then, the décollement is activated beyond the toe of the wedge and a new frontal ramp emerges at a distance that depends on the thickness of the wedge and on the angle between the basal décollement and the thrust (Ruh et al., 2012). When a new thrust sheet is formed, a new conjugate backthrust propagates accordingly. The location of the backthrusts at the rear of the wedge depend on the strain rate along the basal décollement and on the distance from the rigid, perfectly vertical backstop. Since gravity is rotated by $5^{\circ}$, the least principal stress dips northward by $85^{\circ}$. As a result, backthrusts are steeper than forward verging thrusts as they depend on the orientation of the principal stresses. At the wedge toe, backthrusts do not produce significant offsets and strain rates decrease rapidly when a new active frontal thrust is formed.

As shown in previous studies (e.g., Cubas et al., 2008; Ruh et al., 2012), the evolution of the wedge follows closely the prediction of the critical taper theory (Dahlen, 1984) with localized deformation on discrete faults and shear bands. The topographic slope of the resulting wedge thus depends on the dip angle and basal friction of the décollement, and on the strength of the wedge. This means that the slope of the wedge increases with the basal friction strength (Davis et al., 1983). However, without erosion, the wedge grows indefinitely and the force needed to drive deformation would increase as the square of the thickness of the wedge. This 
(a)
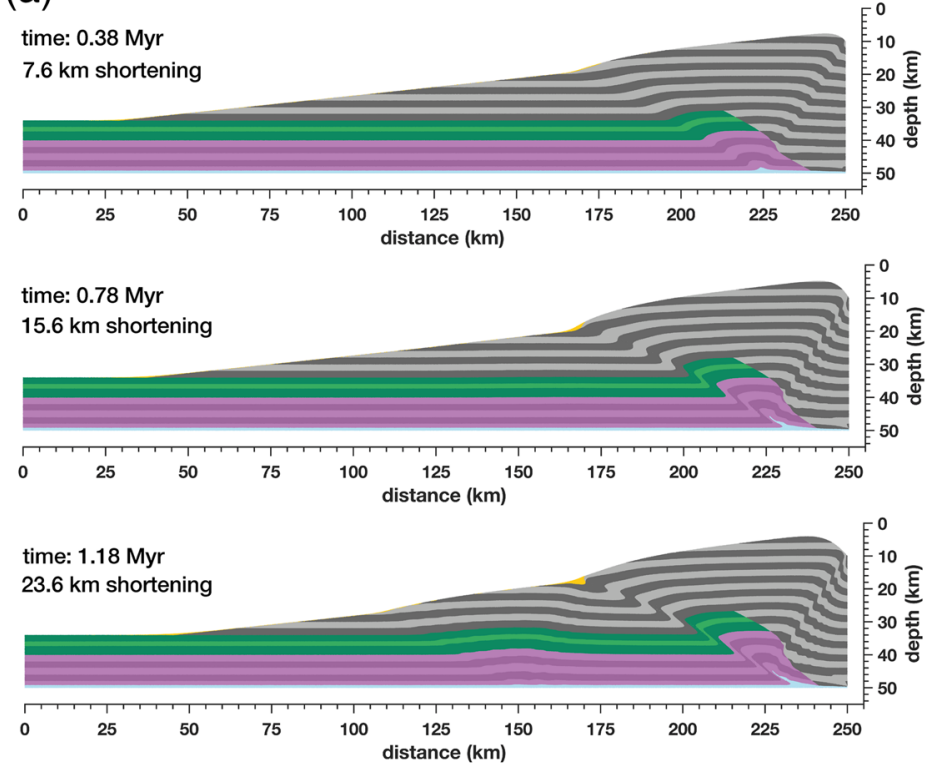

(b)
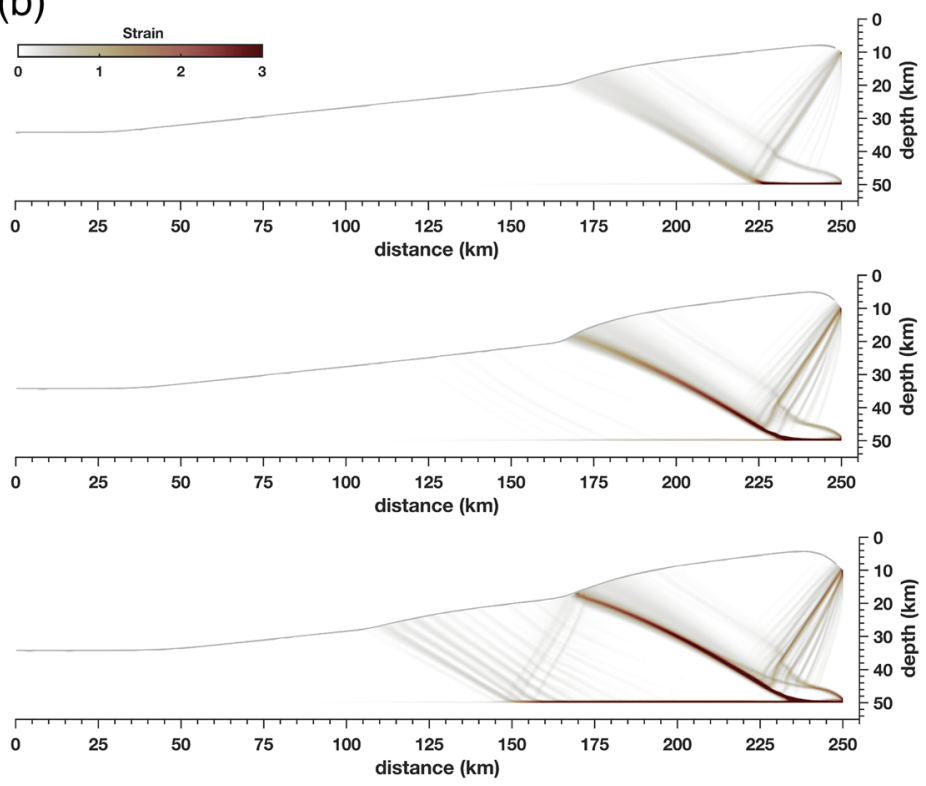

Figure 5. Modeling results with a single d 'ecollement (Model-M1). Temporal evolution of fold-and-thrust belt with a single basal frictional décollement. No erosion takes place (yellow material is the sedimentary cover). (a) Structural evolution of the model; (b) the cumulative plastic strain. The wedge evolves horizontally through an in-sequence thrusting and related backthrusts.

is because the force transmitted at the interface between the underthrusting basement and the overthrusting wedge is the integral of the basal shear stress along the length of the basal contact, which both increase linearly with the thickness of the self-similar wedge.

\subsection{Two Décollements (textModel-M2)}

We performed a second set of numerical experiments in which we added an intermediate frictional décollement layer within the wedge sequence. Results show profound structural differences with respect to simulations with a single basal décollement (Figure 6a). Shear bands and midcrustal ramps bridge the two décollements, thus creating a duplex (Figure 6b).

Horizontal spacing between midcrustal ramps depends on the vertical separation of the two décollements. The outer wedge, which grows by frontal accretion, is controlled entirely by the dip angle and friction of the intermediate décollement. Continuous shortening increases the topography in the inner wedge, and a wedge-scale duplex structure starts to grow. However, without erosion, the wedge grows horizontally and the forward imbrication of midcrustal ramps compensates the vertical thickening of the wedge. There is negligible out-of sequence thrusting above the duplex. Thus, the presence of two décollements in this experiment results in frontal accretion in the outer wedge and underplating at the rear of the wedge. All the shortening at structural levels above the intermediate décollement is taken up by shortening of the outer wedge.

\subsection{Two Décollements and Erosion (Model-M3)}

The evolution of Model-M3 combines frontal accretion and underplating modulated by erosion. Initially, this model evolves nearly identically to Model-M2 with frontal accretion above the intermediate décollement and basal accretion at the rear of the wedge (Figure 7a). The cumulative strain indicates that the upper décollement is activated immediately after the initiation of the model, transferring slip to a frontal thrust where the décollement tips out, overriding the sedimentary basin.

Later on, unlike Model-M2, pervasive erosion above the growing wedge enhances exhumation of the duplex, which is uplifted as a domal structure (Figure $7 \mathrm{~b}$ ). While the crustal material is squeezed horizontally, imbricate frontal thrusts continue to form at both the shallow and deeper crustal level. In the inner wedge, further shortening of the crustal sequence is mainly expressed by localized deformation linked to protracted slip along the intermediate décollement synchronous to basement imbrication at the front. Erosion allows the duplex structure to amplifyby stacking and exhumation of the basal décollement in the internal part of the wedge. In the outer wedge, the fault system results in shallow frontal thrusts, which are imbricated 
(a)

time: $1.18 \mathrm{Myr}$

$23.6 \mathrm{~km}$ shortening

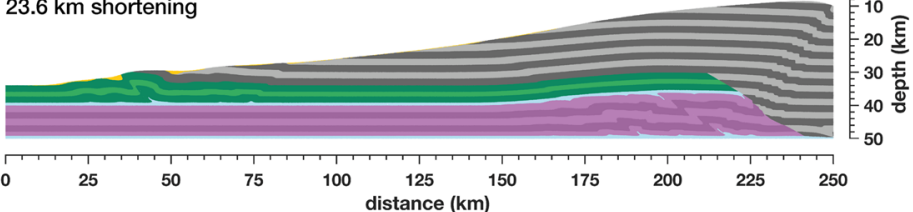

time: $2.38 \mathrm{Myr}$

$47.6 \mathrm{~km}$ shortening
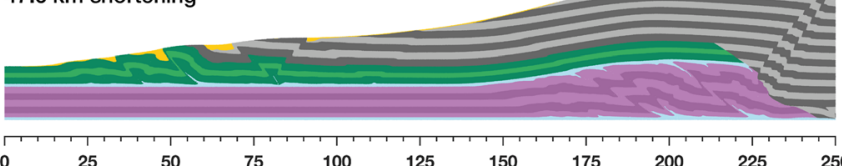

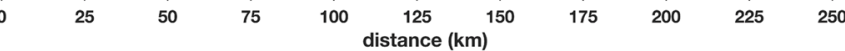

time: $3.58 \mathrm{Myr}$

$71.6 \mathrm{~km}$ shortening

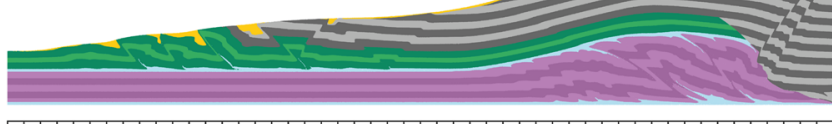

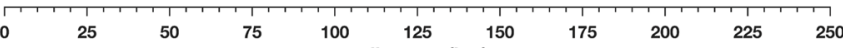

distance $(\mathbf{k m})$

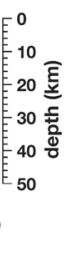

(b)

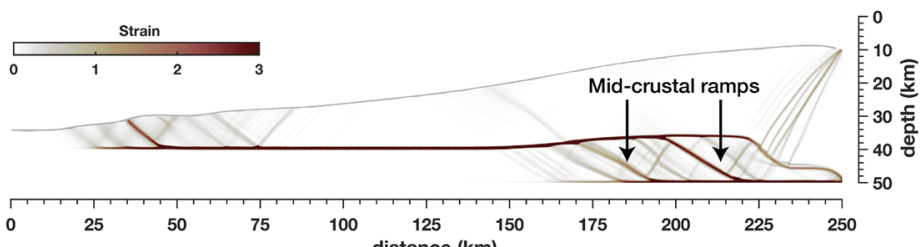

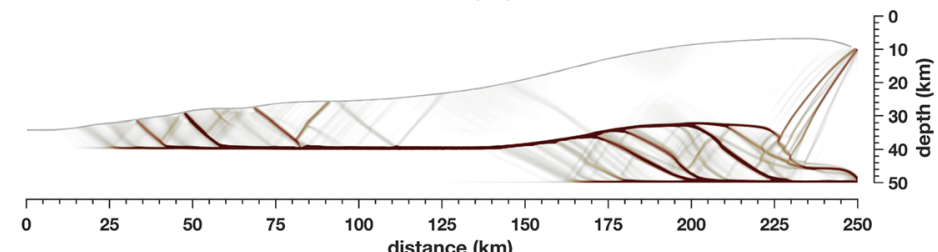

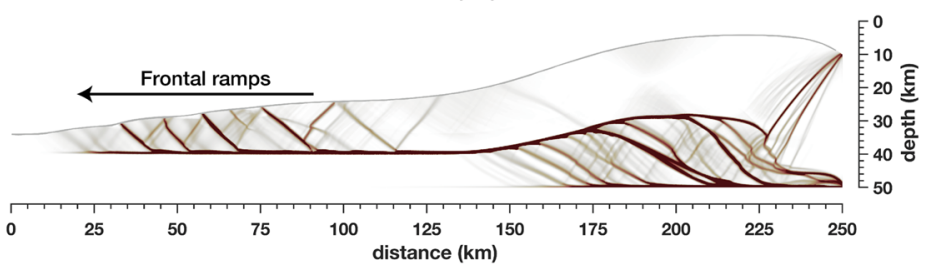

Figure 6. Modeling results with two d 'ecollements (Model-M2). Temporal evolution of fold-and-thrust belt with a basal and an intermediate frictional décollement. No erosion takes place (yellow material is the sedimentary cover). (a) Structural evolution. (b) Accumulated plastic strain. The presence of two décollements produces a forward verging imbrication of shallow ramps at the toe of the wedge, while midcrustal ramps connecting the two décollements propagate from the rear of the model to the outer wedge.

(a)

time: $0.98 \mathrm{Myr}$

$19.6 \mathrm{~km}$ shortening

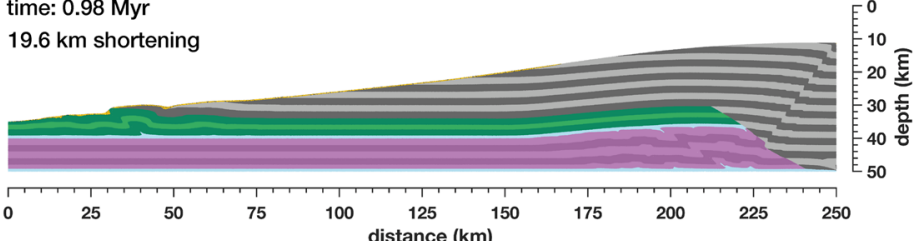

time: $3.98 \mathrm{Myr}$

$79.6 \mathrm{~km}$ shortening

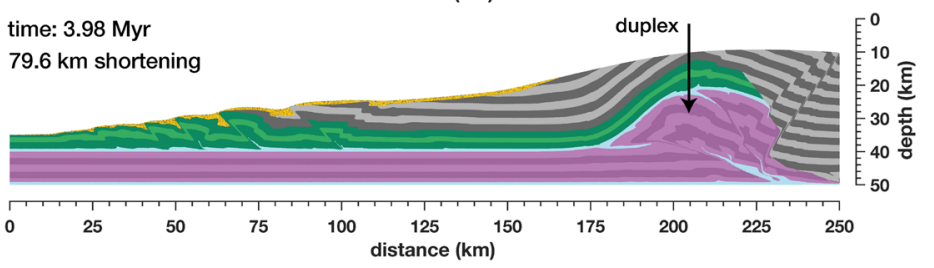

time: $7.98 \mathrm{Myr}$

$159.6 \mathrm{~km}$ shortening

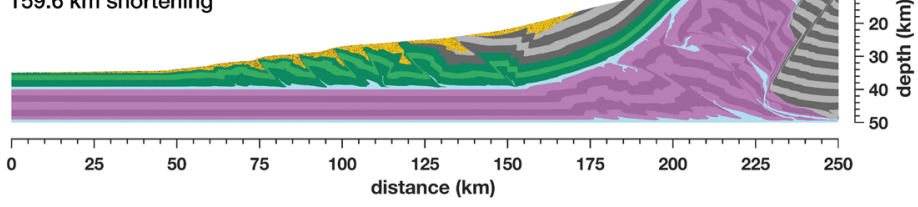

(b)
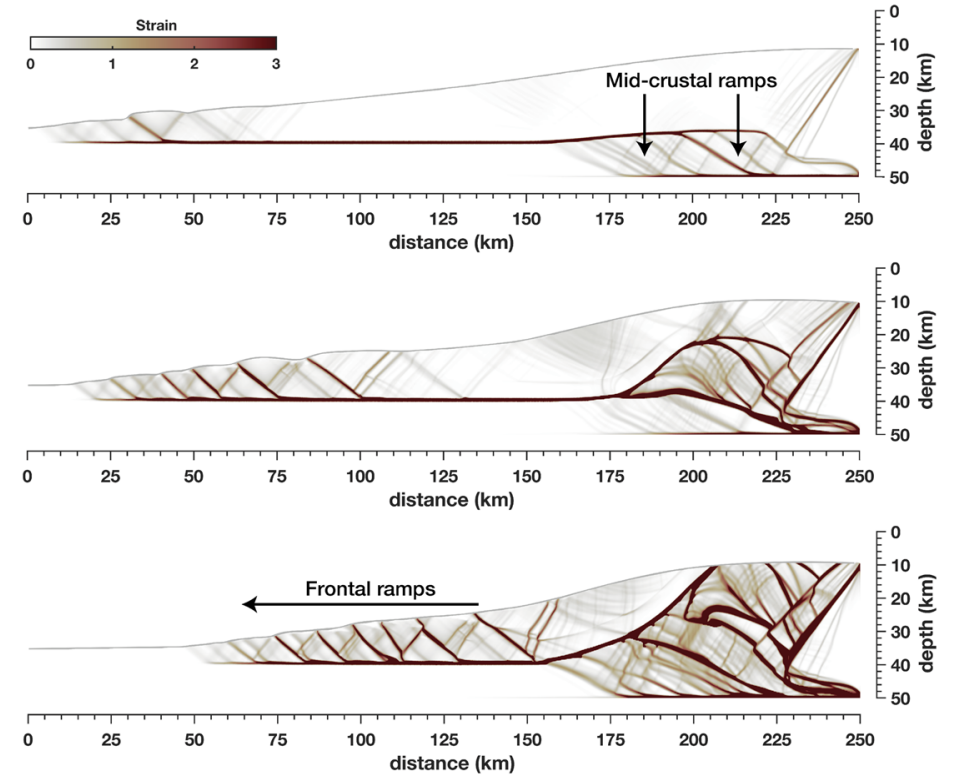

Figure 7. Temporal evolution of the reference Model-M3 with two d 'ecollements and erosion. (a) Structural evolution and (b) cumulative strain (white-to-brown color map). Basal and intermediate décollements consist of thin weak layers. Basal décollement is stronger than intermediate one. Erosion allows for exhumation of the duplex and apparent migration of midcrustal ramps. 
(a)

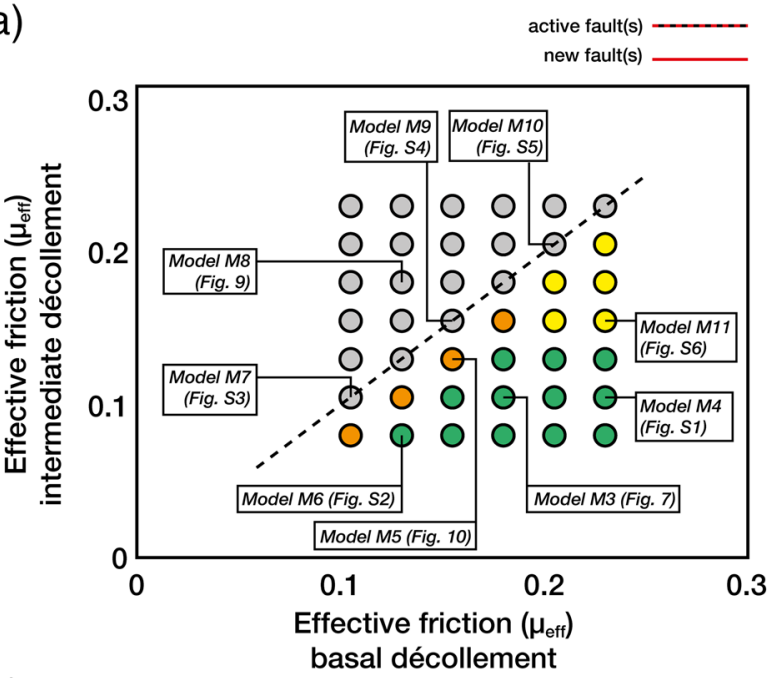

(c)

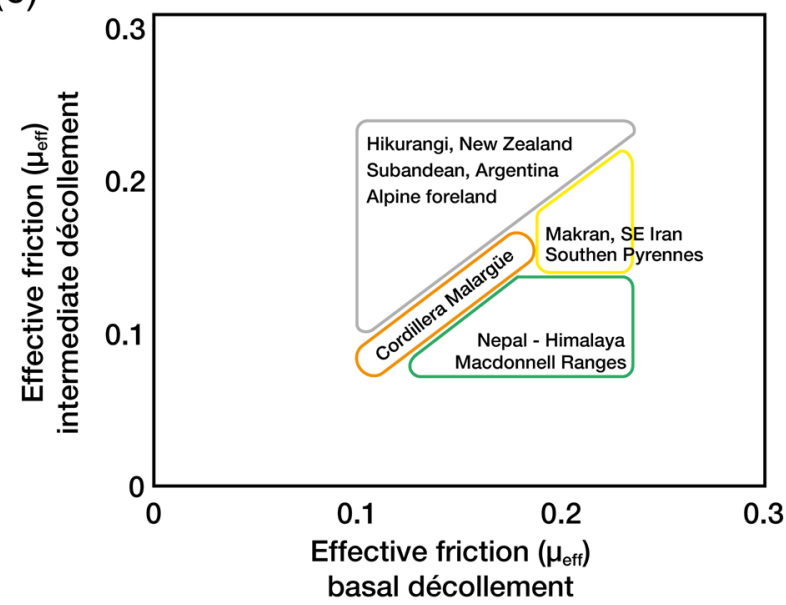

(b)

Single décollement activated, out-of-sequence thrusting

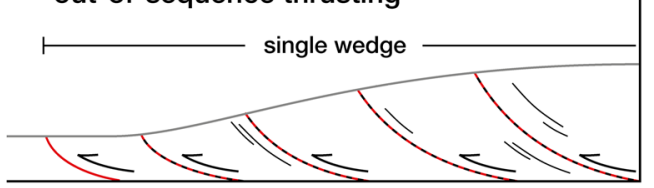

Two décollements activated, out-of-sequence thrusting

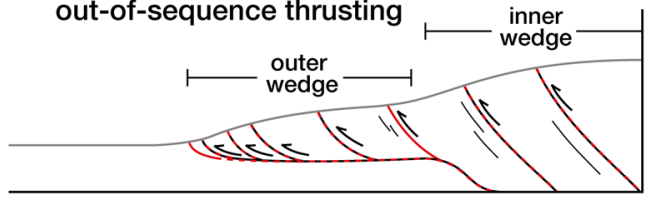

Two décollements activated, duplex, and out-of-sequence thrusting

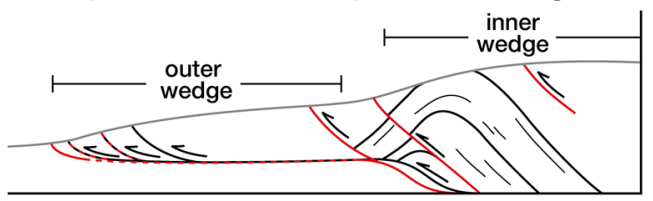

Two décollements activated, duplex, and no out-of-sequence thrusting

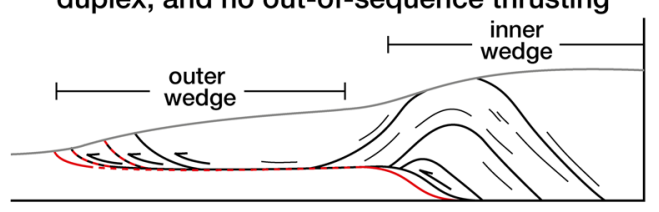

Figure 8. Impact of effective friction of basal and intermediate décollements on the structural evolution of fold-and-thrust belt. (a) Sensitivity test and (b) sketches illustrating the tectonic style expected for different effective frictions values. (c) First-order classification of different fold-and-thrust belts worldwide.

toward the foreland basin and characterized by significant structural relief and related folding of the cover strata. Also, conjugate left-dipping extensional faults become inverted to different degrees, forming backthrusts, imbricate stacks and flower structures. Basement-involved footwall-shortcut thrusts develop from the intermediate décollement to the basal one.

\subsubsection{Effective Friction: Intermediate Versus Basal Décollement}

We then investigate how the structural evolution of our models varies as a function the of the effective friction of the basal and the intermediate décollements (Figure 8). We find that if the basal décollement is weaker than the intermediate one, as, for example, in the case of Model-M8 (Figure 8), the overall cross-sectional taper is controlled by the strength of the weaker basal décollement (gray circles, Figure 8). The structural evolution of the fold-and-thrust belts results in a single wedge rooted in the basal décollement. In this case, out-of-sequence thrusting develops from the front of the wedge toward the rear of model, in which each forward vergent thrust is characterized by a conjugate backthrust. The major difference with the structural evolution of a wedge formed above a single décollement (Model-M1, Figure 5) is that erosion allows significant exhumation leading to distinct inner and outer wedges with exhumation depth limited by the intermediate and basal décollements. When assuming the same frictional strength for the basal and the intermediate décollement, the evolution of the fold-and-thrust belt is characterized by an initial development of midcrustal ramps and is followed by an out-of-sequence thrusting phase (Model-M7, Figure S3 in the supporting information, and Model-M9, Figure S4). The overall geometry still shows a single wedge with out-of-sequence thrusting balancing erosion. When the friction of both the basal and the 
(a)

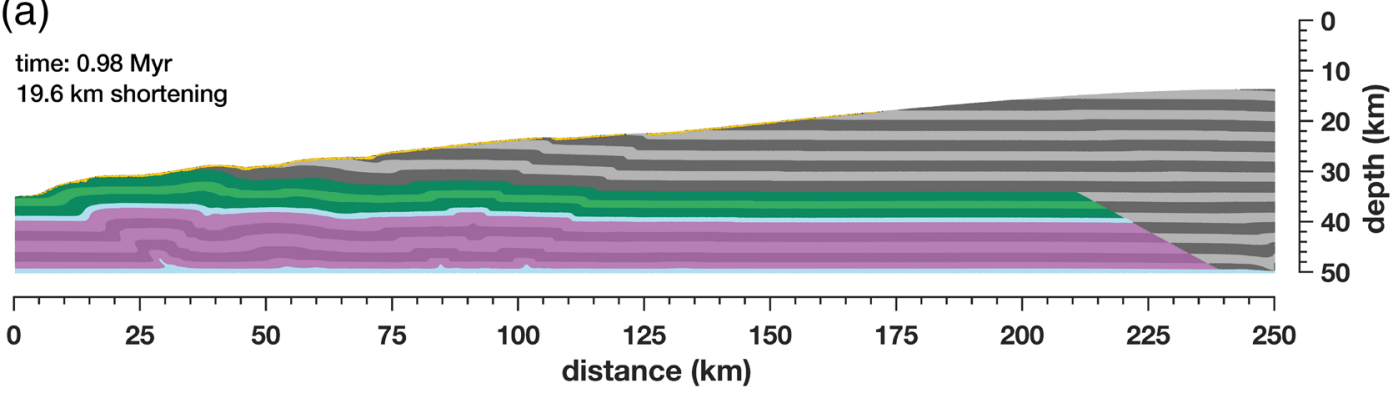

(b)

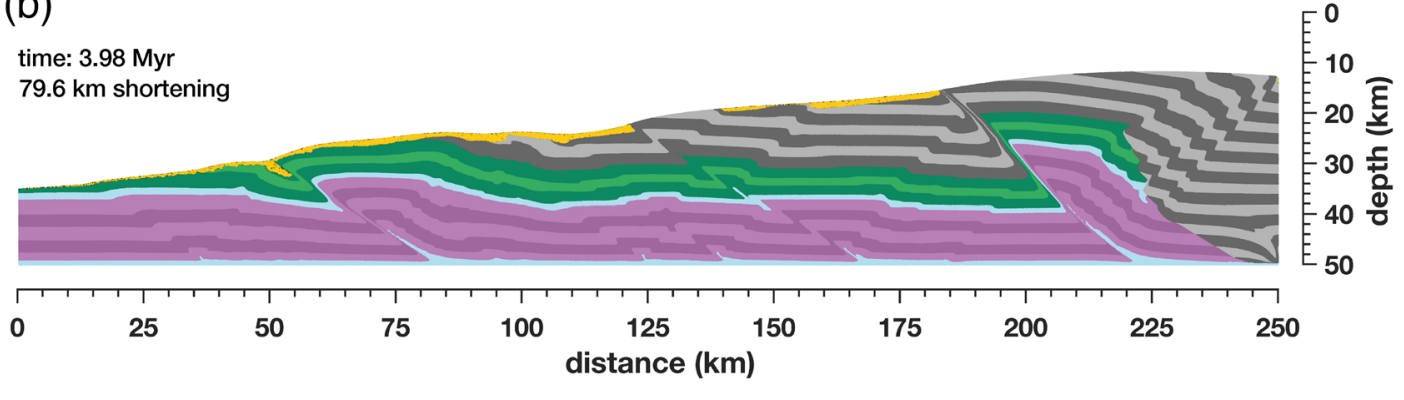

(c)

time: $7.98 \mathrm{Myr}$

$159.6 \mathrm{~km}$ shortening

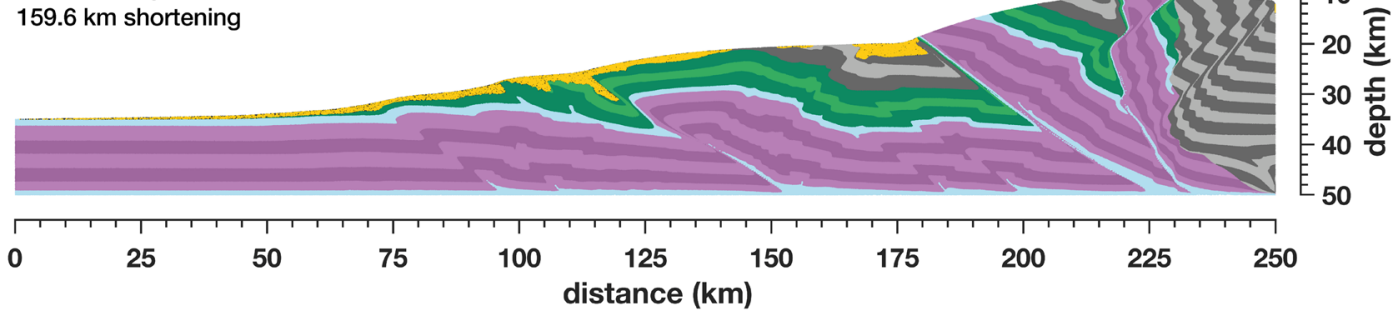

Figure 9. Model with a basal d 'ecollement weaker than the intermediate one and erosion (Model-M8). The overall structural evolution of the model is controlled by the strength of the basal weak layer, which results in a out-of-sequence thrusting.

intermediate décollements are relatively higher (Model-M10, Figure S5), the model is dominated by out-of-sequence thrusting and exhumation of deeper units near the rear part of the wedge.

When the effective friction of the basal décollement is stronger than the intermediate one, the two décollements are activated (yellow, orange, and green circles, Figure 8) leading the formation of midcrustal ramps. Distinct outer and inner wedges are then observed. When the intermediate décollements has a relatively high friction ( $>0.2$ ) (yellow circles, Figure 8), the dominant mechanism controlling the structural evolution of the fold-and-thrust belts is still out-of-sequence thrusting. The slightly lower effective friction of the intermediate décollement results in a lower topographic slope compared to that of the inner wedge, which is controlled by the basal décollement (Model-M11, Figure S6). Higher exhumation rates there results in more rapid rock uplift and more accentuated exhumation in the rear of the model. Ramping of the lower units occurs along irregularly spaced thrusts.

When the effective frictional strength of the intermediate décollement is sufficiently weaker than the basal one (orange and green points, Figure 8), the two décollements are activated and a duplex can form, leading to antiformal stacking. Like in the previous case, the difference in frictional strength between the two décollements leads to the development of an outer wedge, controlled by the intermediate décollement, and an inner wedge, controlled by the basal décollement. When the frictional strength between the two décollements is similar (orange points, Figure 8), tectonic underplating is not sufficient to thicken the inner wedge over longer periods. Consequently, the models result in out-of-sequence thrusting (Model-M8: Figures 9 and Model-M5: Figures 10). If the frictional strength difference between the basal and intermediate 


\section{(a)}

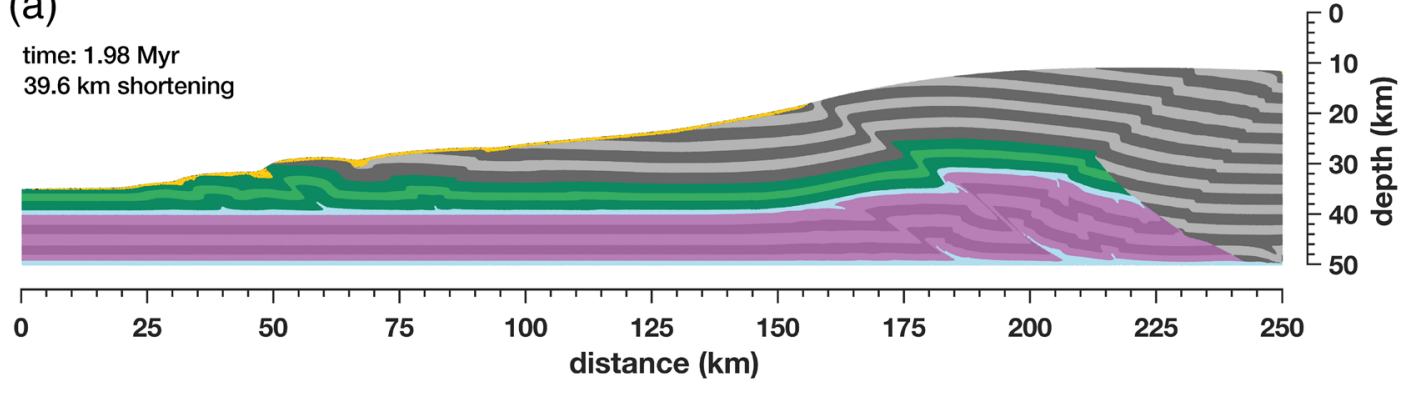

(b)

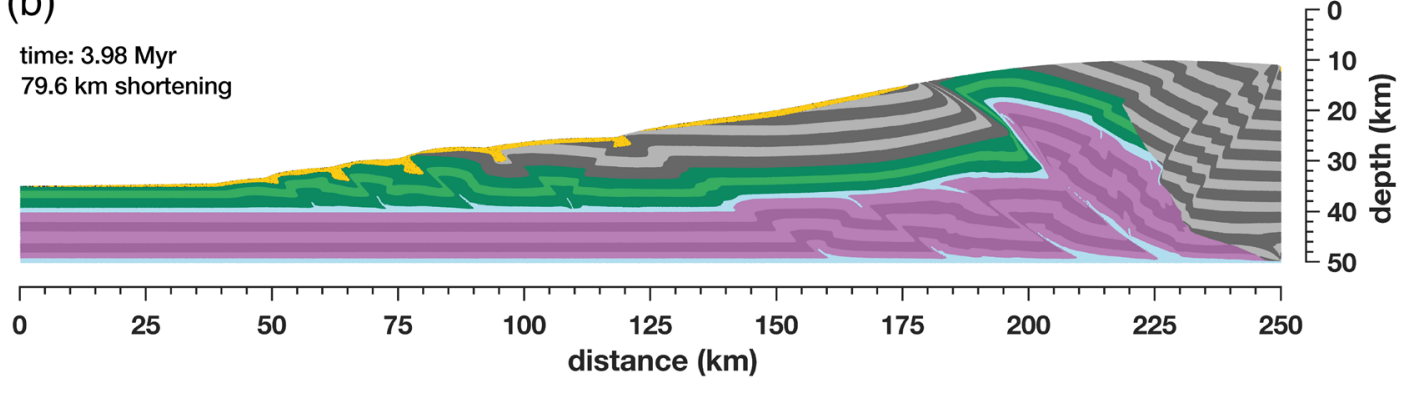

(c)

time: $6.98 \mathrm{Myr}$ $139.6 \mathrm{~km}$ shortening

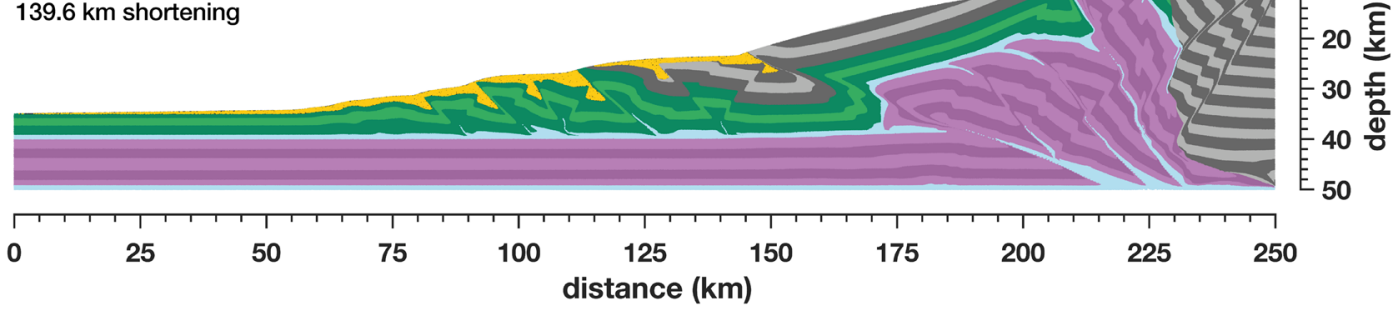

Figure 10. $(\mathrm{a}-\mathrm{c})$ Structural evolution of a model with an intermediate $d$ 'ecollement weaker than the basal one and erosion (Model-M5). The model shows the development of midcrustal ramps, a duplex structure, and out-of-sequence thrusting.

décollements is slightly larger, a structural evolution similar to that of our reference model (Model-M3, Figure 7) is observed (green points, Figure 8). In this case, the model is dominated by underplating, due to the propagation of midcrustal ramps and duplexing (Model-M4, Figure S1, and Model-M6, Figure S2). While thrust ramps develop in a forward vergent manner, backthrusts appear at the rear of the wedge, especially when deformation reaches the internal parts (Figure 7b). Two structural spacing of thrust faults develop in the inner and outer wedge: a short length of horses restricted to the uppermost pile, which is a function of the depth of the intermediate décollement and a relatively broader length of horses, in the rear of the model, which is a function of the basal décollement depth. The long spacing of thrust faults initially arise in the upper part of the rock sequence, with fault propagation folds evolving into midcrustal ramps affecting the whole pile. The fast growth of (partial) fault propagation folds at the toe of the wedge is steeper than the critical taper related to the intermediate décollement and controls the short spacing of thrust faults in the upper pile.

\section{Discussion}

\subsection{Comparison With the Himalaya}

The numerical experiments presented in this study are, in general, comparable to those reported by Konstantinovskaia and Malavieille (2005). They found that a structural evolution similar to that of the Himalaya can arise in the presence of an intermediate décollement within the brittle orogenic wedge due to coupling between erosion and deformation. Despite the simplifications made in the analog experiment 
(a)

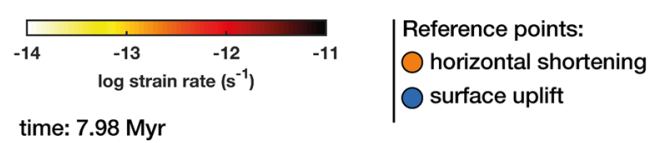

time: $7.98 \mathrm{Myr}$

$159.6 \mathrm{~km}$ shortening

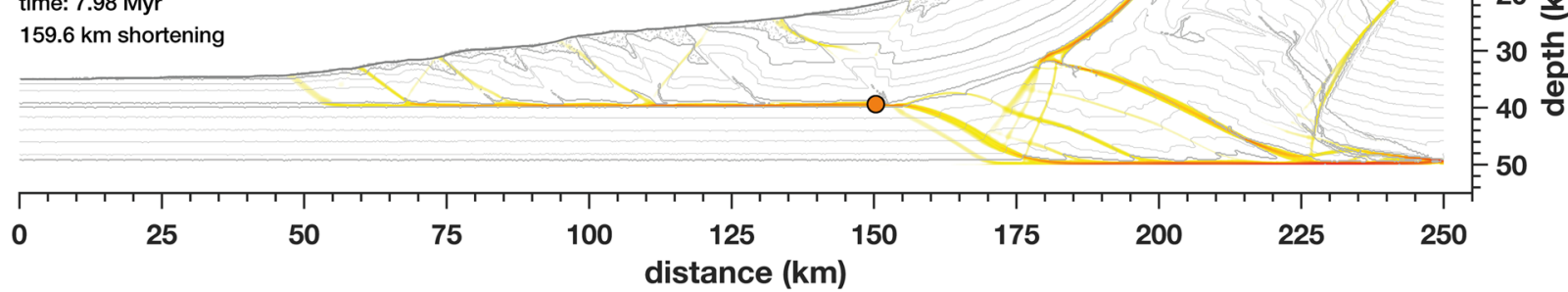

(b)

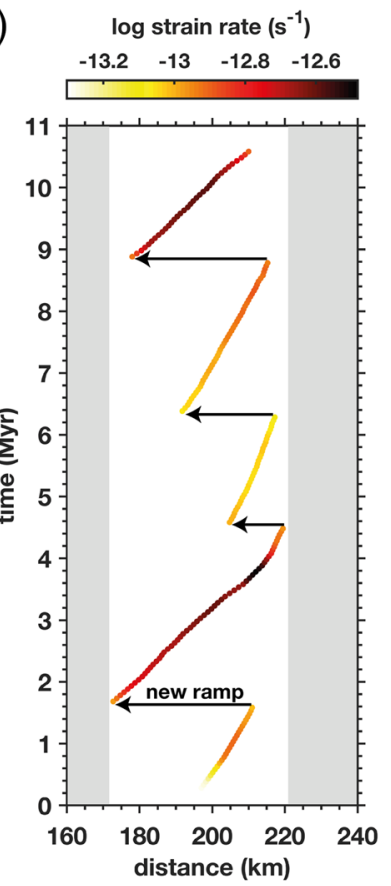

(c)

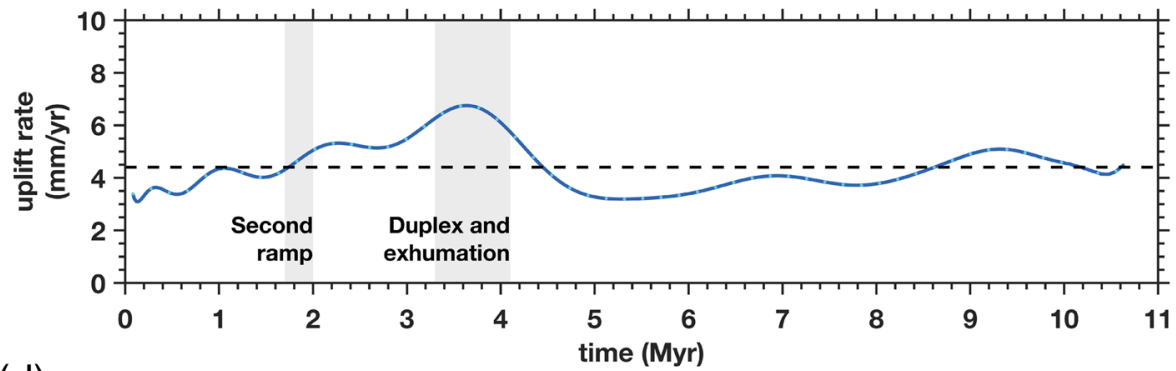

(d)

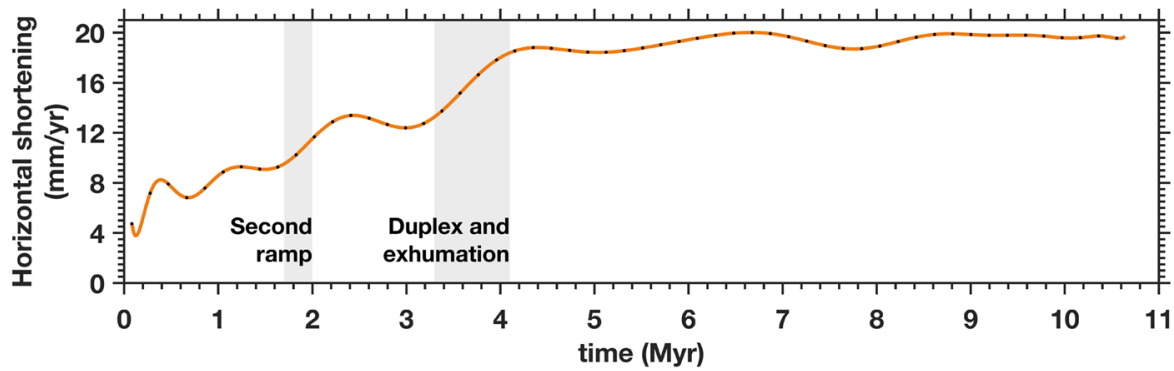

Figure 11. Fold-and-thrust belt evolution (Model-M3). (a) Strain rate distribution and contour of rock composition. Orange and blue circles indicate the reference points where the surface uplift (c) and horizontal shortening (panel d) are measured. (b) Location of the most active midcrustal ramp through time, showing an apparent migration due to a periodic bypass of new ramps. (c) Temporal evolution of uplift rate above the duplex structure. (d) Long-term slip rate measured along the intermediate décollement.

and in our model setup (e.g., rigid basement and no temperature-dependent rheology), it is interesting to investigate the mechanisms that give rise to such a structural evolution.

Our experiments indicate that if the intermediate décollement is weaker than the basal décollement (as in the case of Model-M3, Figure 7), strain localizes on both décollements. The intermediate décollement then connects the outer wedge, which grows through frontal accretion with the inner wedge that is dominated by tectonic underplating. The underlying units, between the intermediate and the basal décollements, are then thrusted and accreted to the hanging wall to form an antiformal stack near the rear of the wedge (Figure 11a). At any given time, the distribution of strain rates shows a strong localization along the resulting flat-ramp-flat system (Figure 11a). Our models show a migration toward the toe of the wedge of the most active midcrustal ramp(s) (Figure 11b). This occurs because erosion does not completely balance uplift due to ramp overthrusting. As a result, the frictional resistance to sliding along the ramp increases. At some point the ramp locks, the basal décollement propagates forward, and a new ramp forms creating a new horse. In Model-M3, a ramp is typically active for 1.5 to $3 \mathrm{Myr}$ and several ramps might be simultaneously active at a given time (Figure 11b). Consequently, uplift is not steady (Figure 11c). It is maximum when one ramp dominates with the peak of uplift rate being located above that ramp. By about $4 \mathrm{Myr}$, the model enters a regime where the entire $20 \mathrm{~mm} \mathrm{yr}^{-1}$ convergence rate is transferred to the intermediate décollement and taken up by thrusting and folding in the outer wedge (Figure 11d) as is currently observed in the Himalaya 
(Burgess et al., 2012; Lavé \& Avouac, 2000; Stevens \& Avouac, 2015). Notably, Model-M3 yields a mean uplift rates of $\sim 4.5 \mathrm{~mm} \mathrm{yr}^{-1}$ above the duplex structure for long-term slip rate of $\sim 19-20 \mathrm{~mm} \mathrm{yr}^{-1}$ (Figure 11d) and thus consistent with values from the trans-Himalayan river incision (Lavé \& Avouac, 2001). This is one reason why this particular model was chosen for the comparison with the Himalayan wedge. Another reason is that it yields topographic slopes comparable to that of the Himalayan wedge.

The mechanics of a wedge evolving over a frictional base is classically approximated using the critical wedge theory (Dahlen, 1984; Dahlen, Suppe, et al., 1984; Davis et al., 1983). The critical wedge theory predicts a minimum and a maximum critical topographic slope angle $(\alpha)$, knowing the dip angle of the basal décollement $(\beta)$, and the internal strength of the wedge material and the basal décollement. Between these two angles, the wedge is stable, meaning that it can slide along its base without any internal deformation (Figure 12). If the wedge is critical, it fails in extension for the steeper (critical) topographic slopes (dashed line in Figure 12) and in compression for the shallower topographic slopes (continuous line in Figure 12). In our experiment, as in analog sandbox experiments with a similar setup, the wedge gradually evolves toward a critical geometry in compression. It is interesting to compare the wedge geometry obtained in our numerical experiments with that expected for the critical taper theory.

Model-M3 has a friction coefficient of 0.10 on the intermediate décollement and 0.18 on the basal one (Figure 12a). Accordingly, the critical taper angle related to the intermediate décollement is lower than that resulting from the basal décollement (Figure 12b). When the wedge reaches a critically unstable condition, the evolution through time of the topography yields an average surface slope angle of $\sim 0.8^{\circ}$ for the outer wedge and $\sim 3.7^{\circ}$ for the inner wedge. In the flounder diagram (Figure 12c), these values of surface slope and décollement dip angle (i.e., $5^{\circ}$ ) match well the critical values for an effective friction of 0.10 for the intermediate décollement and 0.18 for the basal décollement. The digital elevation model ETOPO1 (Amante \& Eakins, 2009), used to measure the average topographic slopes across the Himalaya, indicates an average topographic slope of $\sim 0.9^{\circ}$ between the Sub-Himalaya and Lesser Himalaya, and $\sim 4.0^{\circ}$ in the High Himalaya, and thus remarkably similar to those predicted by Model-M3. This range of values is consistent with the effective friction of 0.25 obtained by Davis et al. (1983), in which they considered the whole Himalayan wedge as a single wedge $(\alpha=4 \pm 0.5)$ and assumed a lower dip angle of the basal décollement ( $\beta=3 \pm 1.0$ ). We conclude that the effective friction along the flat portion of the MHT that extends beneath the Lesser Himalaya to the Sub-Himalaya must be of the order of 0.1-0.2. On the other hand, the basal shear stress along the subhorizontal ductile shear zone, which extends beneath the High Himalaya and southern Tibet, must be of the order of $\sim 80 \mathrm{MPa}$.

We calculated the dip angle of the midcrustal ramps $\left(\theta_{r}\right)$ using the analytical solution proposed in Dahlen (1984):

$$
\psi_{b}=\frac{1}{2} \arcsin \left(\frac{\sin \varphi_{b}^{\prime}}{\sin \varphi}\right)-\frac{1}{2} \varphi_{b}^{\prime},
$$

where $\psi_{b}$ is the angle between the basal décollement and the principal stress, whereas $\varphi$ and $\varphi_{b}^{\prime}$ are the effective friction angle (i.e., including pore fluid pressure) of the wedge and basal décollement, respectively. The angle between the inclination of the midcrustal ramps and the maximum principal stress appear to be according to the Coulomb angle:

$$
\theta_{c}=45-\frac{\varphi}{2}
$$

The difference between $\psi_{b}$ and $\theta_{c}$ gives an expected dip angle value of the midcrustal ramps $\left(\theta_{r}\right)$ of $~ 27.7$. This value is comparable to the dip angle of the midcrustal ramp in Nepal, which has been inferred from geodetic data, combined with geologic and geophysical analyses (e.g., Duputel et al., 2016; Elliott et al., 2016; Hubbard et al., 2016).

Our estimate of the effective basal friction of $\sim 0.1$ on the flat portion of the MHT beneath the Lesser Himalaya is also in agreement with estimate obtained previously from numerical models of the Himalayan seismic cycle (Cattin \& Avouac, 2000; Dal Zilio et al., 2019), which require values between 0.1 and 0.2. Other analyses based on inversion of the thermochronological and thermobarometric data from central Nepal (Herman et al., 2010), as well as microseismic activity and shear stress threshold (Bollinger, Avouac, Cattin et al., 2004), indicate a basal friction between 0.07 and 0.1 , respectively. The effective friction angle 
(a)

(b)
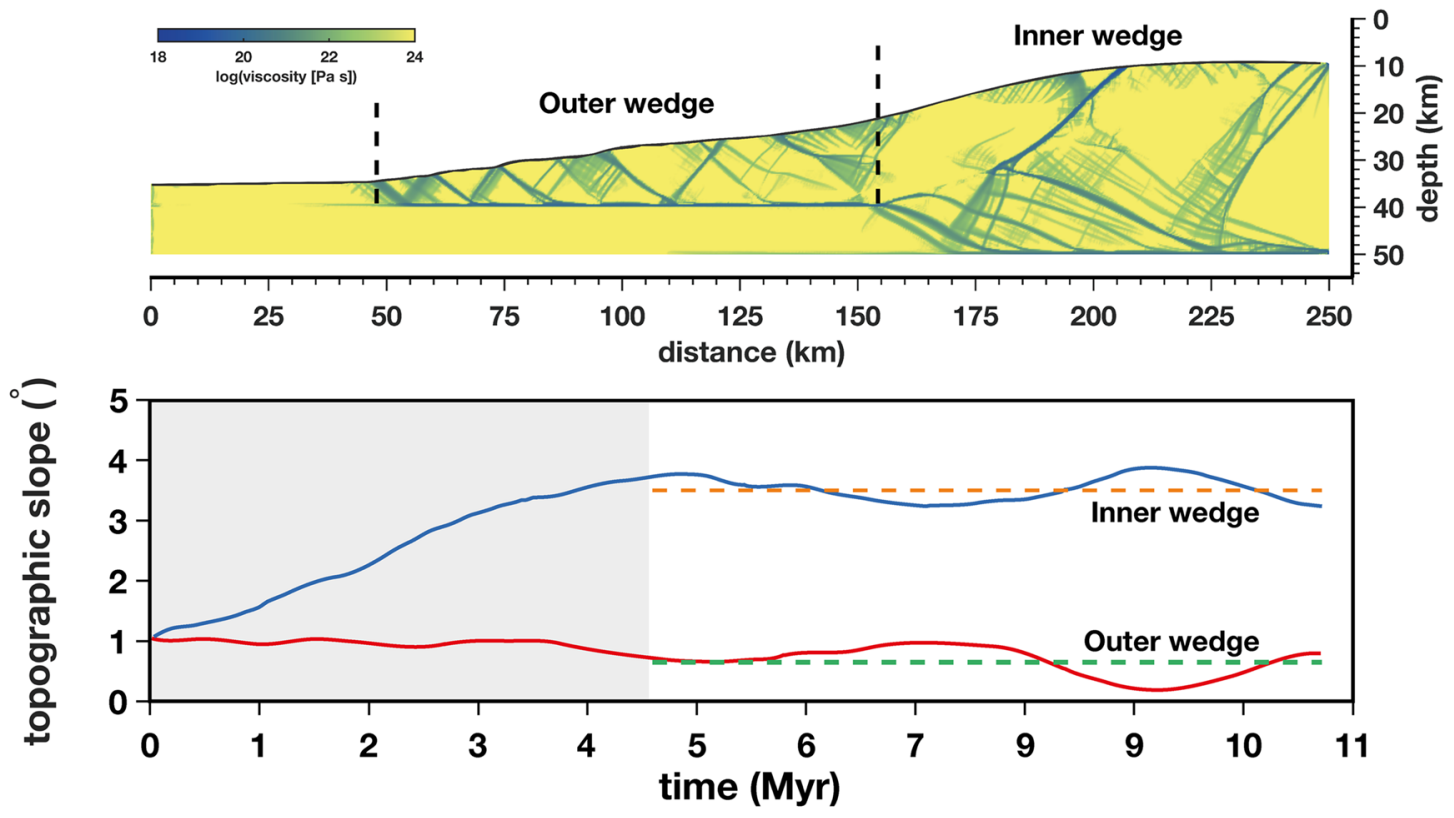

(c)

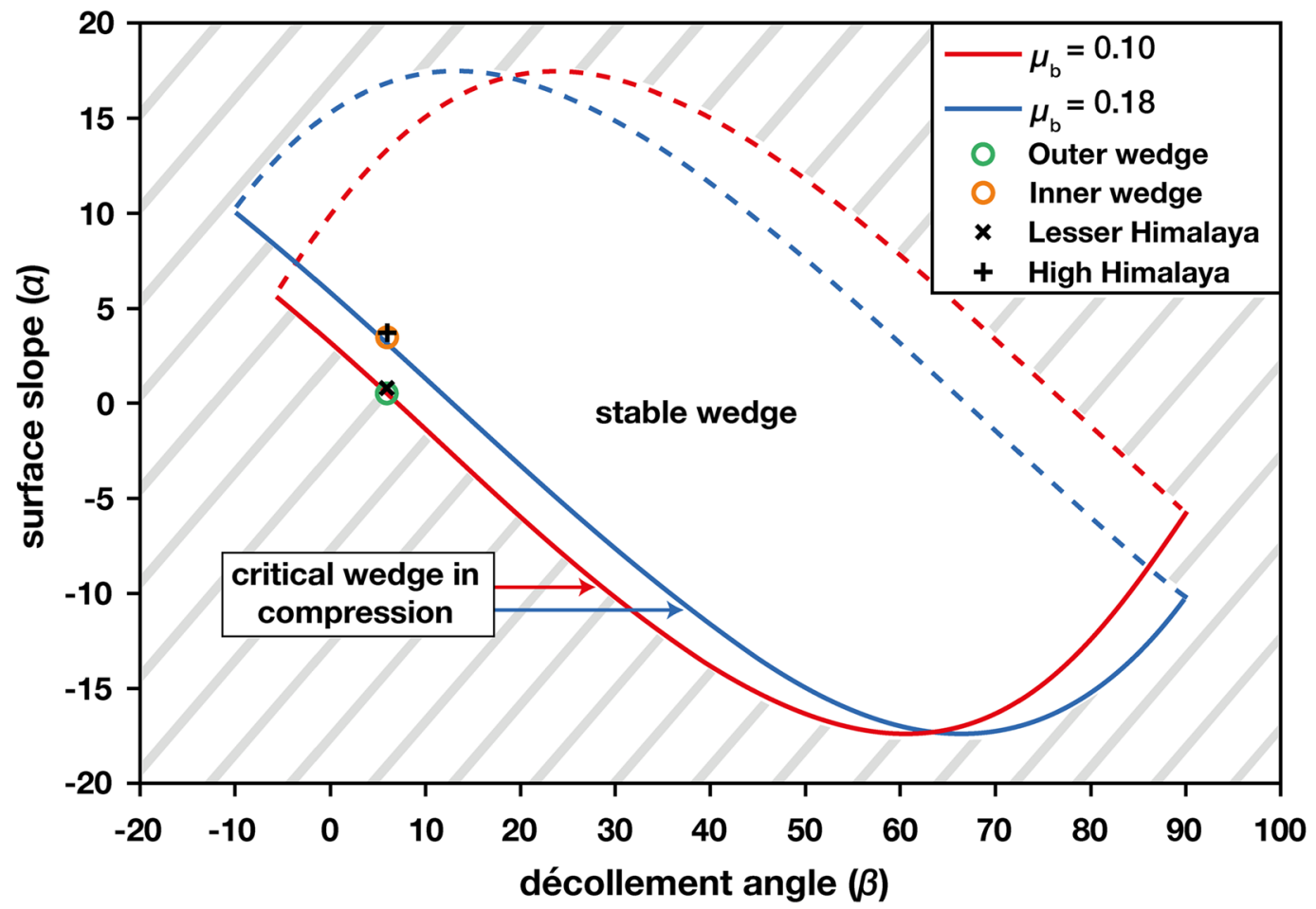

Figure 12. Application of a critical wedge taper model to constrain fault friction of the Main Himalayan Thrust. (a) Viscosity distribution of Model-M3 (time: $7.98 \mathrm{Myr}$ ) showing the final fold-and-thrust belt structure divided in inner and outer wedge. (b) Temporal evolution of the topographic slope in the inner and outer wedge. Dashed lines indicates the corresponding average values measured once the wedge is critically unstable (time $>4.7 \mathrm{Myr}$ ). (c) Flounder diagrams of the stability of frictional wedge with an internal friction of $\phi_{i}=30^{\circ}$ and basal friction angles of $\phi_{b}=10.4^{\circ}$ and $5.8^{\circ}$ relating the basal and intermediate décollements, respectively. Orange and green circles indicate the values of surface $(\alpha)$ and base ( $\beta$ ) angles from Model-M3. Black crosses indicate the corresponding values from the Lesser and High Himalaya. The wedge is stable within the flounder-shaped and unstable in extension (dashed lines) and in compression (continuous line). 
along the MHT must be low, of the order of 0.1, a value significantly lower than the typical friction of 0.6 to 0.8 measured on dry rock samples in the laboratory (Byerlee, 1978).

The low effective friction on the shallow and brittle portion of the MHT might be related to a particularly weak lithology. Décollements have been found to often coincide with evaporitic or shale formations (e.g., DeCelles \& Coogan, 2006; Sommaruga, 1999), which are thought to deform primarily by ductile mechanisms. However, this explanation seems unlikely in the Himalaya as there is no candidate lithologies in the Lesser Himalaya where they should have been exhumed. Alternatively, the low friction along the MHT is caused by dynamic weakening. The MHT appears fully locked during the interseismic periods along its complete length over $\sim 100 \mathrm{~km}$ width (Dal Zilio, Jolivet, et al., 2020; Stevens \& Avouac, 2015), which implies that it slips mainly during seismic slip events. Thus, the low friction could be due to dynamic effects such as frictional melting (e.g., Di Toro et al., 2011) and hydrodynamic lubrication (e.g., Kanamori \& Brodsky, 2004), thermal pressurization of pore fluids (e.g., Noda \& Lapusta, 2013), decarbonation (e.g., Rowe et al., 2012; Sulem \& Famin, 2009), and phyllonites generated by the breakdown of load-bearing feldspar (Gueydan et al., 2003; Jefferies et al., 2006; O'Hara, 2007). While decarbonation implies the presence of carbonates, which are unlikely to be present at the level of the MHT, permeable cataclasis can promote the infiltration of fluids which, in turn, cause the breakdown of feldspar and the formation of phyllonites. In particular, the breakdown of feldspar-and the associated strength reduction-occur at temperatures of $200-400^{\circ} \mathrm{C}$ (O'Hara, 2007) and thus prior to the conditions for the weakening of quartz. Such weakening mechanism, which has already been proposed for nappe stacking in the Alps (Pfiffner, 2016; Scheiber et al., 2012), may hold for the MHT as well. Highly foliated Chlorite-Biotite phyllites are well documented in the hanging wall rocks of the MHT (Pêcher, 1989; Schelling \& Arita, 1991), which suggest that these rocks were intensely deformed with a shear strain parallel to the thrust fault. However, the formation of Chlorite-Biotite phyllites is primarily a ductile process (e.g., pressure solution). Therefore, this process probably occurs at depth greater than the interseismically locked portion of the MHT. As the metamorphic units are thrusted on the MHT, the phyllonites could contribute to the low apparent friction of the MHT. However, the friction coefficient of most micas is larger than 0.2 (Byerlee, 1978; Moore \& Lockner, 2004). This suggests that other mechanisms, such as dynamic weakening during seismic slip, are required to explain the friction lower than 0.2 that we estimated from our analysis.

Fluids, which have been found as fluid inclusions in quartz lenses (Boullier et al., 1991), can explain a transient weak friction due to pore pressurization at midcrustal levels. In Nepal, magnetotelluric data detected a major zone of high electrical conductivity south of the High Himalaya, a feature that can be explained by $\sim 3 \%$ aqueous fluid porosity (Lemonnier et al., 1999). These fluids originate partly from metamorphic dehydration reactions of underthrust Indian basement (Boullier et al., 1991), percolate upward through the deformed brittle media, and accumulate within the possibly impermeable MHT shear zone at $\sim 20 \mathrm{~km}$ depth, near the ramp-flat transition (Lemonnier et al., 1999), a region known for its low seismic wave velocity (Acton et al., 2011; Caldwell et al., 2013; Duputel et al., 2016; Hetényi, 2007; Nábělek et al., 2009; Subedi et al., 2018).

\subsection{Comparison to Fold-and-Thrust Belts Worldwide}

A number of orogenic wedges show distinct inner and outer wedges with crystalline units exhumed from midcrustal depth in the inner wedge (see, Pfiffner, 2017, for a review, and Figure 1 for some examples). This geometry arises in our numerical experiments if the deeper décollement is weaker than the shallower one (orange, yellow, and green circles in Figure 8). Some examples show evidence for out-of-sequence thrusting within the inner wedge (e.g., the Malargüe cordillera in the Andes; Figure 1). Some others exhibit, like the Himalaya, a duplex system and antiformal culmination in the inner wedge: These example include the Pyrenees (e.g., Martínez \& Vergés, 1988) and the Apallachians (e.g., Kulander \& Dean, 1986) (Figure 1). Such crustal-scale geometry is relatively generic because, as seen in numerical experiments accounting for a realistic geometry and rheological layering at the lithospheric scale (e.g., D'Acquisto et al., 2020; Dal Zilio, Kissling, et al., 2020; Selzer et al., 2008), (1) the thrust fault system must at some point root in a zone of thermally activated ductile deformation forming a deep-seated décollement and (2) décollement levels naturally form at shallower depth either at the contact between the sediments and the crystalline basement or within the sedimentary cover. These shallower décollements might appear weak due to particularly weak lithologies prone to ductile deformation under low shear stress, as is the case for the evaporite layers in the Jura Mountains 
(e.g., Sommaruga, 1999). The Jura Mountains (Figure 1) are a good example in which the presence of weak evaporitic deposits at a depth of 2,000 to 3,000 m served as décollement level, thus leading to a single wedge system similarly to our numerical experiments represented by the gray circles in Figure 8 . However, there is evidence that, following the deformation of the décollement, the crystalline basement has also been involved in the deformation. The amount of shortening in the basement seems minimal and occurred during a later stage of the building of the Jura Mountains (Pfiffner, 2014). Notably, the décollement beneath the Jura Mountains can be traced all along the Central Alps (Figure 1), where it reaches the crystalline basement. In this case, the external massifs (e.g., Aar, Mont-Blanc, Aiguilles-Rouges, and Belledonne Massifs) are part of an inner wedge (e.g., Pfiffner, 2017).

Duplex structures and antiformal stacking can similarly form at smaller scale due to the simultaneous activation of multiple décollement levels. An example of multiple décollements is the Sub-Andean fold-and-thrust belt, NW Argentina, which is one of the most active thin-skinned fold-and-thrust belts in a retroarc setting (Echavarria et al., 2003). The presence of Silurian shale at the base of the belt is responsible for the eastward verging in-sequence thrusting and fault-bend anticlines. At shallow levels, the presence of upper Devonian shales within the stratigraphic sequence explain the occurrence of folds with steep flanks and narrow crests. In this case, the overall fold-and-thrust belt structure relates to a combined effect of underplating and out-of-sequence thrusting, similar to the models represented by the orange circles in Figure 8.

\subsection{Modeling Limitations}

In terms of geometry and rheology, the setup adopted in our numerical experiments is a very simplified representation of natural examples of orogenic wedges. The point was to facilitate the analysis of how duplex systems emerge and result in large antiformal culmination. We however recognize that in view of the simplifications comparison with natural examples should be done with caution. Our model considers only a brittle wedge over a rigid basement. Apart from the two décollements, our numerical experiments assume the same frictional strength. This mean that our models resemble mostly the deformation of a sedimentary wedge with multiple décollements (Ruh et al., 2012). The horizontally layered lithologies are pushed over a rigid, perfectly vertical backstop. At the rear of the wedge, imbricate shear bands develop as conjugate thrusts, whereas backthrusts bifurcate from the basal décollement, and their location is affected by the vertical backstop.

We ignored the direct weakening effect of temperature on rheology (e.g., Shinevar et al., 2015), which might influence the deformation style of the deeper crustal layers. As discussed above, the deeper décollement in our experiment can be seen as representing a thermally activated ductile shear zone, which can arise spontaneously from thermomechanical numerical models (Dal Zilio et al., 2019).

The assumption of a rigid basement is also an oversimplification as flexural bending and anelastic deformation of the basement can occur in nature. For example, the Zagros fold-and-thrust belt might be a seen as a large scale single wedge formed over an evaporitic basal décollement to first order, but basement faulting is also clearly documented (Vergés et al., 2011) and is predicted in thermomechanical models depending on the assumed temperature gradient (Nilfouroushan et al., 2013). Finally, in nature, tectonic deformation is three-dimensional while our model assumes plane strain. This means that our two-dimensional plane strain model cannot account of the effects of lateral variations of mechanical properties or the effect of lateral propagation of deformation.

\section{Conclusions}

We used a 2-D finite difference numerical model with a visco-elasto-plastic rheology to systematically investigate how deformation coupled with erosion control the structural evolution of orogenic wedges. We adopted a simplified setup to facilitate comparing results with results from analog experiments (e.g., Konstantinovskaya \& Malavieille, 2011; Lohrmann et al., 2003; Santimano et al., 2015) and with the critical wedge theory (Dahlen, Suppe, et al., 1984; Davis et al., 1983), which uses similar geometrical boundary conditions. The main results can be summarized as follows:

1. Simulations with a single frictional décollement lead to forward verging in-sequence thrusting forming ramps with dip angles depending on the wedge-internal stress orientation (Figure 5). In particular, a single wedge is formed with a geometry close to that predicted by the critical taper theory. 
2. The presence of an intermediate décollement strongly influences the structural evolution of fold-and-thrust belts allowing for both frontal accretion and tectonic underplating to occur. If the basal décollement is weaker than the intermediate décollement, two distinct outer and inner wedges are formed (Figure 7). The outer wedge grows by frontal accretion while the inner wedge grows as a result of underplating, leading to a duplex system and antiformal stacking, and out-of-sequence thrusting (Figure 9).

3. For models with erosion and an intermediate décollement weaker than the basal décollement, all the deformation is transferred to the frontal outer wedge. The resulting structural style reflects to a first-order the Himalayan fold-and-thrust belt (Figure 7). Apparent migration of midcrustal ramps, tectonic underplating, crustal-scale duplexing, and antiformal stacking can be sustained over longer timescales only when erosion allows for exhumation of crustal material. This is the structural evolution observed in the analog experiments of, for example, Konstantinovskaya and Malavieille (2011).

4. Underplating in the inner wedge occurs through a combined effect of episodic migration of midcrustal ramps and erosion. When the frictional resistance to sliding along the ramp increases, the ramp locks while the basal décollement propagates forward and a new ramp forms, thus creating a new horse. As a result, the growth of the wedge is episodic as it depends on the position of the most active midcrustal ramp (Figure 11b).

5. Our numerical experiments demonstrate that an intermediate décollement weaker than the basal one is needed to reproduce underplating in the accretionary wedge and the sharp topography gradient between the Lesser and High Himalaya (Figure 12). Our results indicate an effective friction of 0.10 for the intermediate décollement and an apparent friction of 0.18 for the basal décollement, which probably stands for ductile shear zone in reality. The low friction on the intermediate décollement, which extends from beneath the Lesser Himalaya to the Sub-Himalaya is probably due to dynamic weakening during seismic slip events.

Our analysis illustrates how the presence of multiple potential décollement levels and the coupling between deformation and erosion can result in different structural evolutions, allowing for some simple first-order classification of orogenic wedges.

\section{Data Availability Statement}

Data related to this paper can be downloaded from the following link (https://doi.org/10.22002/D1.1388).

\section{Acknowledgments}

This study was funded by the Swiss National Science Foundation (SNSF) Early Postdoc.Mobility fellowship (P2EZP2_184307) and the Cecil and Sally Drinkward fellowship at Caltech (L. D. Z.). Numerical simulations were performed on ETH cluster Euler. We thank A. Yin, A. Webb, J. Lavé, M. Searle, R. Jolivet, and J.-P. Burg for constructive comments and discussions. We thank Adrian Pfiffner and Oriol Pla for their constructive comments, which helped improve the paper considerably.

\section{References}

Acton, C. E., Priestley, K., Mitra, S., \& Gaur, V. K. (2011). Crustal structure of the Darjeeling—Sikkim Himalaya and Southern Tibet. Geophysical Journal International, 184(2), 829-852.

Ader, T., Avouac, J.-P., Liu-Zeng, J., Lyon-Caen, H., Bollinger, L., Galetzka, J., et al. (2012). Convergence rate across the Nepal Himalaya and interseismic coupling on the Main Himalayan Thrust: Implications for seismic hazard. Journal of Geophysical Research, 117, B04403. https://doi.org/10.1029/2011JB009071

Amante, C., \& Eakins, B. W. (2009). ETOPO1 arc-minute global relief model: Procedures, data sources and analysis.

Andrews, D. J., \& Bucknam, R. C. (1987). Fitting degradation of shoreline scarps by a nonlinear diffusion model. Journal of Geophysical Research, 92(B12), 12,857-12,867.

Avouac, J.-P. (2015). Mountain building: From earthquakes to geologic deformation. Treatise on Geophysics, 6, 381-432.

Avouac, J.-P., \& Burov, E. B. (1996). Erosion as a driving mechanism of intracontinental mountain growth. Journal of Geophysical Research, 101(B8), 17,747-17,769.

Bilham, R., Larson, K., \& Freymueller, J. (1997). GPS measurements of present-day convergence across the Nepal Himalaya. Nature, 386(6620), 61-64.

Bollinger, L., Avouac, J. P., Beyssac, O., Catlos, E. J., Harrison, T. M., Grove, M., et al. (2004). Thermal structure and exhumation history of the lesser Himalaya in central Nepal. Tectonics, 23, TC5015. https://doi.org/10.1029/2003TC001564

Bollinger, L., Avouac, J. P., Cattin, R., \& Pandey, M. R. (2004). Stress buildup in the Himalaya. Journal of Geophysical Research, 109, B11405. https://doi.org/10.1029/2003JB002911

Bollinger, L., Henry, P., \& Avouac, J. P. (2006). Mountain building in the Nepal Himalaya: Thermal and kinematic model. Earth and Planetary Science Letters, 244(1), 58-71.

Borderie, S., Graveleau, F., Witt, C., \& Vendeville, B. C. (2018). Impact of an interbedded viscous décollement on the structural and kinematic coupling in fold-and-thrust belts: Insights from analogue modeling. Tectonophysics, 722, 118-137.

Boullier, A.-M., France-Lanord, C., Dubessy, J., Adamy, J., \& Champenois, M. (1991). Linked fluid and tectonic evolution in the high Himalaya Mountains (Nepal). Contributions to Mineralogy and Petrology, 107(3), 358-372.

Boyer, S. E., \& Elliott, D. (1982). Thrust systems. Aapg Bulletin, 66(9), 1196-1230.

Brunel, M. (1986). Ductile thrusting in the Himalayas: Shear sense criteria and stretching lineations. Tectonics, 5(2), $247-265$.

Burbank, D. W., Blythe, A. E., Putkonen, J., Pratt-Sitaula, B. G. A. B. E. T., Gabet, E., Oskin, M., et al. (2003). Decoupling of erosion and precipitation in the Himalayas. Nature, 426(6967), 652. 
Burgess, W. P., Yin, A., Dubey, C. S., Shen, Z.-K., \& Kelty, T. K. (2012). Holocene shortening across the main frontal thrust zone in the eastern Himalaya. Earth and Planetary Science Letters, 357, 152-167.

Burkhard, M., \& Sommaruga, A. (1998). Evolution of the western Swiss Molasse basin: Structural relations with the Alps and the Jura belt. Geological Society, London, Special Publications, 134(1), 279-298.

Byerlee, J. (1978). Friction of rocks. In Rock friction and earthquake prediction (pp. 615-626). Birkháuser, Basel: Springer.

Caldwell, W. B., Klemperer, S. L., Lawrence, J. F., Rai, S. S., \& Ashish (2013). Characterizing the main Himalayan thrust in the Garhwal Himalaya, India with receiver function CCP stacking. Earth and Planetary Science Letters, 367, 15-27.

Carter, N. L., Hansen, F. D., \& Senseny, P. E. (1982). Stress magnitudes in natural rock salt. Journal of Geophysical Research, 87(B11), 9289-9300

Cattin, R., \& Avouac, J. P. (2000). Modeling mountain building and the seismic cycle in the Himalaya of Nepal. Journal of Geophysical Research, 105(B6), 13,389-13,407.

Célérier, J., Harrison, T. M., Beyssac, O., Herman, F., Dunlap, W. J., \& Webb, A. A. G. (2009). The Kumaun and Garwhal Lesser Himalaya, India: Part 2. Thermal and deformation histories. Geological Society of America Bulletin, 121(9-10), 1281-1297.

Coutand, I., Whipp, D. M., Grujic, D., Bernet, M., Fellin, M. G., Bookhagen, B., et al. (2014). Geometry and kinematics of the Main Himalayan Thrust and neogene crustal exhumation in the Bhutanese Himalaya derived from inversion of multithermochronologic data. Journal of Geophysical Research: Solid Earth, 119, 1446-1481. https://doi.org/10.1002/2013JB010891

Cubas, N., Leroy, Y. M., \& Maillot, B. (2008). Prediction of thrusting sequences in accretionary wedges. Journal of Geophysical Research, 113, B12412. https://doi.org/10.1029/2008JB005717

D'Acquisto, M., Dal Zilio, L., Molinari, I., Kissling, E., Gerya, T., \& van Dinther, Y. (2020). Tectonics and seismicity in the northern apennines driven by slab retreat and lithospheric delamination. Tectonophysics, 789, 228481. https://doi.org/10.1016/j.tecto.2020.228481

Dahlen, F. A. (1984). Noncohesive critical coulomb wedges: An exact solution. Journal of Geophysical Research, 89(B12), 10,125-10,133.

Dahlen, F. A., Suppe, J., \& Davis, D. (1984). Mechanics of fold-and-thrust belts and accretionary wedges: Cohesive coulomb theory. Journal of Geophysical Research, 89(B12), 10,087-10,101.

Dal Zilio, L., Jolivet, R., \& van Dinther, Y. (2020). Segmentation of the Main Himalayan Thrust illuminated by Bayesian inference of interseismic coupling. Geophysical Research Letters, 47, e2019GL086424. https://doi.org/10.1029/2019GL086424

Dal Zilio, L., Kissling, E., Gerya, T., \& van Dinther, Y. (2020). Slab Rollback Orogeny model: A test-of-concept. Geophysical Research Letters, e2020GL089917. https://doi.org/10.1029/2020GL089917

Dal Zilio, L., van Dinther, Y., Gerya, T., \& Avouac, J.-P. (2019). Bimodal seismicity in the Himalaya controlled by fault friction and geometry. Nature communications, 10(1), 48.

Dal Zilio, L., van Dinther, Y., Gerya, T. V., \& Pranger, C. C. (2018). Seismic behaviour of mountain belts controlled by plate convergence rate. Earth and Planetary Science Letters, 482, 81-92.

Davis, D., Suppe, J., \& Dahlen, F. A. (1983). Mechanics of fold-and-thrust belts and accretionary wedges. Journal of Geophysical Research, 88(B2), 1153-1172.

DeCelles, P. G., \& Coogan, J. C. (2006). Regional structure and kinematic history of the Sevier fold-and-thrust belt, central Utah. Geological Society of America Bulletin, 118(7-8), 841-864.

DeCelles, P. G., Robinson, D. M., Quade, J., Ojha, T. P., Garzione, C. N., Copeland, P., \& Upreti, B. N. (2001). Stratigraphy, structure, and tectonic evolution of the Himalayan fold-thrust belt in western Nepal. Tectonics, 20(4), 487-509.

Di Toro, G., Han, R., Hirose, T., De Paola, N., Nielsen, S., Mizoguchi, K., et al. (2011). Fault lubrication during earthquakes. Nature, 471(7339), 494-498.

Duputel, Z., Vergne, J., Rivera, L., Wittlinger, G., Farra, V., \& Hetényi, G. (2016). The 2015 Gorkha earthquake: A large event illuminating the Main Himalayan Thrust fault. Geophysical Research Letters, 43, 2517-2525. https://doi.org/10.1002/2016GL068083

Echavarria, L., Hernández, R., Allmendinger, R., \& Reynolds, J. (2003). Subandean thrust and fold belt of northwestern Argentina: Geometry and timing of the andean evolution. AAPG bulletin, 87(6), 965-985.

Elliott, J. R., Jolivet, R., González, P. J., Avouac, J.-P., Hollingsworth, J., Searle, M. P., \& Stevens, V. L. (2016). Himalayan megathrust geometry and relation to topography revealed by the Gorkha earthquake. Nature Geoscience, 9, 174-180.

Gansser, A. (1964). Geology of the Himalayas.

Gerya, T., \& Yuen, D. (2007). Robust characteristics method for modelling multiphase visco-elasto-plastic thermo-mechanical problems. Physics of the Earth and Planetary Interiors, 163(1), 83-105.

Gerya, T. V., \& Yuen, D. A. (2003). Characteristics-based marker-in-cell method with conservative finite-differences schemes for modeling geological flows with strongly variable transport properties. Physics of the Earth and Planetary Interiors, 140(4), 293-318.

Ghosh, S., Bose, S., Mandal, N., \& Laik, A. (2020). Mid-crustal ramping of the main Himalayan thrust in Nepal to Bhutan Himalaya: New insights from analogue and numerical experiments. Tectonophysics, 782-783, 228425.

Gillespie, P. A., Walsh, J. J., \& Watterson, J. (1992). Limitations of dimension and displacement data from single faults and the consequences for data analysis and interpretation. Journal of Structural Geology, 14(10), 1157-1172.

Gleason, G. C., \& Tullis, J. (1995). A flow law for dislocation creep of quartz aggregates determined with the molten salt cell. Tectonophysics, 247(1), 1-23.

Grandin, R., Doin, M.-P., Bollinger, L., Pinel-Puysségur, B., Ducret, G., Jolivet, R., \& Sapkota, S. N. (2012). Long-term growth of the Himalaya inferred from interseismic InSAR measurement. Geology, 40(12), 1059-1062.

Gueydan, F., Leroy, Y. M., Jolivet, L., \& Agard, P. (2003). Analysis of continental midcrustal strain localization induced by microfracturing and reaction-softening. Journal of Geophysical Research, 108(B2), 2064. https://doi.org/10.1029/2001JB000611

Gutscher, M.-A., Kukowski, N., Malavieille, J., \& Lallemand, S. (1998). Episodic imbricate thrusting and underthrusting: Analog experiments and mechanical analysis applied to the alaskan accretionary wedge. Journal of Geophysical Research, 103(B5), $10,161-10,176$.

Hauck, M. L., Nelson, K. D., Brown, L. D., Zhao, W., \& Ross, A. R. (1998). Crustal structure of the Himalayan orogen at 90 east longitude from project INDEPTH deep reflection profiles. Tectonics, 17(4), 481-500.

Herman, F., Copeland, P., Avouac, J.-P., Bollinger, L., Mahéo, G., Le Fort, P., et al. (2010). Exhumation, crustal deformation, and thermal structure of the Nepal Himalaya derived from the inversion of thermochronological and thermobarometric data and modeling of the topography. Journal of Geophysical Research, 115, B06407. https://doi.org/10.1029/2008JB006126

Hetényi, G. (2007). Evolution of deformation of the Himalayan prism: From imaging to modelling (Ph.D. Thesis), École Normale Supérieure-Université Paris-Sud XI.

Hubbard, J., Almeida, R., Foster, A., Sapkota, S. N., Bürgi, P., \& Tapponnier, P. (2016). Structural segmentation controlled the $2015 \mathrm{Mw}$ 7.8 Gorkha earthquake rupture in Nepal. Geology, 44(8), 639-642. 
Jackson, M., \& Bilham, R. (1994). Constraints on Himalayan deformation inferred from vertical velocity fields in Nepal and Tibet. Journal of Geophysical Research, 99, 13-897.

Jefferies, S. P., Holdsworth, R. E., Wibberley, C. A. J., Shimamoto, T., Spiers, C. J., Niemeijer, A. R., \& Lloyd, G. E. (2006). The nature and importance of phyllonite development in crustal-scale fault cores: An example from the median tectonic line, Japan. Journal of Structural Geology, 28(2), 220-235.

Kanamori, H., \& Brodsky, E. E. (2004). The physics of earthquakes. Reports on Progress in Physics, 67(8), 1429.

Konstantinovskaia, E., \& Malavieille, J. (2005). Erosion and exhumation in accretionary orogens: Experimental and geological approaches. Geochemistry, Geophysics, Geosystems, 6, Q02006. https://doi.org/10.1029/2004GC000794

Konstantinovskaya, E., \& Malavieille, J. (2011). Thrust wedges with décollement levels and syntectonic erosion: A view from analog models. Tectonophysics, 502(3), 336-350.

Kukowski, N., Lallemand, S. E., Malavieille, J., Gutscher, M.-A., \& Reston, T. J. (2002). Mechanical decoupling and basal duplex formation observed in sandbox experiments with application to the western mediterranean ridge accretionary complex. Marine Geology, 186(1-2), 29-42.

Kulander, B. R., \& Dean, S. L. (1986). Structure and tectonics of central and southern Appalachian Valley and ridge and plateau provinces, West Virginia and Virginia. AAPG Bulletin, 70(11), 1674-1684.

Lavé, J., \& Avouac, J.-P. (2000). Active folding of fluvial terraces across the Siwaliks Hills, Himalayas of central Nepal. Journal of Geophysical Research, 105(B3), 5735-5770.

Lavé, J., \& Avouac, J. P. (2001). Fluvial incision and tectonic uplift across the Himalayas of central Nepal. Journal of Geophysical Research, 106(B11), 26,561-26,591.

Le Fort, P. (1975). Himalayas: The collided range. Present knowledge of the continental arc. American Journal of Science, 275(1), 1-44.

Lemonnier, C., Marquis, G., Perrier, F., Avouac, J.-P., Chitrakar, G., Kafle, B., et al. (1999). Electrical structure of the Himalaya of central Nepal: High conductivity around the mid-crustal ramp along the MHT. Geophysical Research Letters, 26(21), 3261-3264.

Lohrmann, J., Kukowski, N., Adam, J., \& Oncken, O. (2003). The impact of analogue material properties on the geometry, kinematics, and dynamics of convergent sand wedges. Journal of Structural Geology, 25(10), 1691-1711.

Martínez, A., \& Vergés, M. (1988). Corte compensado del pirineo oriental: Geometr'ia de las cuencas del antepa'is y edades de emplazamiento de los mantos de corrimiento. Acta Geologica Hispanica, 23(2), 95-105.

Meigs, A. J., Burbank, D. W., \& Beck, R. A. (1995). Middle-late miocene (>10 Ma) formation of the main boundary thrust in the western Himalaya. Geology, 23(5), 423-426.

Moore, D. E., \& Lockner, D. A. (2004). Crystallographic controls on the frictional behavior of dry and water-saturated sheet structure minerals. Journal of Geophysical Research, 109, B03401. https://doi.org/10.1029/2003JB002582

Morley, C. K. (1988). Out-of-sequence thrusts. Tectonics, 7(3), 539-561.

Nábělek, J., Hetényi, G., Vergne, J., Sapkota, S., Kafle, B., Jiang, M., et al. (2009). Underplating in the Himalaya-Tibet collision zone revealed by the Hi-CLIMB experiment. Science, 325(5946), 1371-1374.

Nilfouroushan, F., Pysklywec, R., Cruden, A., \& Koyi, H. (2013). Thermal-mechanical modeling of salt-based mountain belts with pre-existing basement faults: Application to the Zagros fold and thrust belt, southwest Iran. Tectonics, 32, 1212-1226. https://doi.org/ $10.1002 /$ tect.20075

Noda, H., \& Lapusta, N. (2013). Stable creeping fault segments can become destructive as a result of dynamic weakening. Nature, 493(7433), 518.

O'Hara, K. (2007). Reaction weakening and emplacement of crystalline thrusts: Diffusion control on reaction rate and strain rate. Journal of Structural Geology, 29(8), 1301-1314.

Pandey, M. R., Tandukar, R. P., Avouac, J. P., Lave, J., \& Massot, J. P. (1995). Interseismic strain accumulation on the Himalayan crustal ramp (Nepal). Geophysical Research Letters, 22(7), 751-754.

Pêcher, A. (1989). The metamorphism in the central Himalaya. Journal of Metamorphic Geology, 7(1), 31-41.

Pfiffner, O. A. (2014). Geology of the Alps. John Wiley \& Sons.

Pfiffner, O. A. (2016). Basement-involved thin-skinned and thick-skinned tectonics in the Alps. Geological Magazine, 153(5-6), 1085-1109. Pfiffner, O. A. (2017). Thick-skinned and thin-skinned tectonics: A global perspective. Geosciences, 7(3), 71.

Platt, J. P. (1990). Thrust mechanics in highly overpressured accretionary wedges. Journal of Geophysical Research, 95(B6), 9025-9034.

Prager, W., \& Drucker, D. C. (1952). Soil mechanics and plastic analysis or limit design, 0. Applied Mathematics, 10(2), 157-165.

Ranalli, G. (1995). Rheology of the Earth (2nd ed., p. 413). New York: Chapman and Hall.

Robinson, D. M. (2008). Forward modeling the kinematic sequence of the Central Himalayan Thrust belt, western Nepal Himalayan thrust belt, western Nepal. Geosphere, 4(5), 785-801.

Rowe, C. D., Fagereng, A. A., Miller, J. A., \& Mapani, B. (2012). Signature of coseismic decarbonation in dolomitic fault rocks of the Naukluft Thrust, Namibia. Earth and Planetary Science Letters, 333, 200-210.

Ruh, J. B. (2017). Effect of fluid pressure distribution on the structural evolution of accretionary wedges. Terra Nova, 29(3), 202-210.

Ruh, J. B., Kaus, B. J. P., \& Burg, J.-P. (2012). Numerical investigation of deformation mechanics in fold-and-thrust belts: Influence of rheology of single and multiple décollements. Tectonics, 31, TC3005. https://doi.org/10.1029/2011TC003047

Santimano, T., Rosenau, M., \& Oncken, O. (2015). Intrinsic versus extrinsic variability of analogue sand-box experiments-Insights from statistical analysis of repeated accretionary sand wedge experiments. Journal of Structural Geology, 75, 80-100.

Scheiber, T., Pfiffner, O. A., \& Schreurs, G. (2012). Strain accumulation during basal accretion in continental collision-A case study from the Suretta Nappe (eastern Swiss Alps). Tectonophysics, 579, 56-73.

Schelling, D., \& Arita, K. (1991). Thrust tectonics, crustal shortening, and the structure of the far-eastern Nepal Himalaya. Tectonics, 10(5), 851-862.

Schmeling, H., Babeyko, A. Y., Enns, A., Faccenna, C., Funiciello, F., Gerya, T., et al. (2008). A benchmark comparison of spontaneous subduction models-Towards a free surface. Physics of the Earth and Planetary Interiors, 171(1), 198-223.

Selzer, C., Buiter, S. J. H., \& Pfiffner, O. A. (2008). Numerical modeling of frontal and basal accretion at collisional margins. Tectonics, 27, TC3001. https://doi.org/10.1029/2007TC002169

Shen, L., Jia, D., Zhang, Z., Chen, Z., Yin, H., Wu, X., et al. (2020). Tectonic underplating versus out-of-sequence thrusting beneath the lesser Himalaya: Insights from the analogue modeling of the Nepal Himalaya fold-and-thrust belt. Journal of Asian Earth Sciences, 198, 104167.

Shinevar, W. J., Behn, M. D., \& Hirth, G. (2015). Compositional dependence of lower crustal viscosity. Geophysical Research Letters, 42, 8333-8340. https://doi.org/10.1002/2015GL065459

Simpson, G. D. H. (2006). Modelling interactions between fold-thrust belt deformation, foreland flexure and surface mass transport. Basin Research, 18(2), 125-143. 
Simpson, G. D. H. (2009). Mechanical modelling of folding versus faulting in brittle-ductile wedges. Journal of Structural Geology, 31(4), 369-381.

Sommaruga, A. (1999). Décollement tectonics in the jura foreland fold-and-thrust belt. Marine and Petroleum Geology, 16(2), 111-134.

Srivastava, P., \& Mitra, G. (1994). Thrust geometries and deep structure of the outer and Lesser Himalaya, Kumaon and Garhwal (India): Implications for evolution of the Himalayan fold-and-thrust belt. Tectonics, 13(1), 89-109.

Stevens, V. L., \& Avouac, J. P. (2015). Interseismic coupling on the main Himalayan Thrust. Geophysical Research Letters, $42,5828-5837$. https://doi.org/10.1002/2015GL064845

Stockmal, G. S., Beaumont, C., Nguyen, M., \& Lee, B. (2007). Mechanics of thin-skinned fold-and-thrust belts: Insights from numerical models. Geological Society of America Special Papers, 433, 63-98.

Subedi, S., Hetényi, G., Vergne, J., Bollinger, L., Lyon-Caen, H., Farra, V., et al. (2018). Imaging the moho and the main Himalayan thrust in western Nepal with receiver functions. Geophysical Research Letters, 45, 13,222-13,230. https://doi.org//10.1029/2018GL080911

Sulem, J., \& Famin, V. (2009). Thermal decomposition of carbonates in fault zones: Slip-weakening and temperature-limiting effects. Journal of Geophysical Research, 114, B03309. https://doi.org/10.1029/2008JB006004

Vergés, J., Saura, E., Casciello, E., Fernandez, M., Villaseñor, A., Jimenez-Munt, I., \& García-Castellanos, D. (2011). Crustal-scale cross-sections across the NW Zagros belt: Implications for the Arabian margin reconstruction. Geological Magazine, 148(5-6), 739-761.

Webb, A. A. G. (2013). Preliminary balanced palinspastic reconstruction of Cenozoic deformation across the Himachal Himalaya (northwestern India). Geosphere, 9(3), 572-587.

Willett, S. D. (1999). Orogeny and orography: The effects of erosion on the structure of mountain belts. Journal of Geophysical Research, 104(B12), 28,957-28,981.

Wobus, C., Heimsath, A., Whipple, K., \& Hodges, K. (2005). Active out-of-sequence thrust faulting in the central Nepalese Himalaya. Nature, 434(7036), 1008-1011.

Yin, A. (2006). Cenozoic tectonic evolution of the Himalayan orogen as constrained by along-strike variation of structural geometry, exhumation history, and foreland sedimentation. Earth-Science Reviews, 76(1-2), 1-131

Yin, A., \& Harrison, T. M. (2000). Geologic evolution of the Himalayan-Tibetan orogen. Annual Review of Earth and Planetary Sciences, 28(1), 211-280. 